\title{
Kamuoyu Araştırmalarında Tutarlılık Sorunsalı: 2010-2018 Dönemi Kamuoyu Araştırmaları Üzerine Bir İnceleme
}

\author{
The Problem of Consistency in Public Opinion Polls: An Analysis on Public Opinion \\ Polls for 2010-2018
}

\section{Oğuz GÖKSU*}

\section{Öz}

Seçimlere yönelik bazı kamuoyu araştırmaları ile seçim sonuçları arasında çok ciddi farklar olması vatandaşların kamuoyu araştırmalarının güvenilirliğini sorgulamasına neden olmaktadır. Bu çalışmada, Türkiye'de 2010 sonrasında yapılan seçimlere yönelik kamuoyu araştırmaları ile bu araştırmaların medyayla ve siyasal katılmayla ilişkisi sorgulanmaktadır. Çalışmada, son dokuz seçimde 18 farklı kamuoyu araştırma şirketinin açıkladığı araştırma sonuçları ile kesin seçim sonuçları karşılaştırılmaktadır. Buna bağlı olarak seçimlere yönelik kamuoyu araştırmalarının siyasal süreçlerde güvenin inşa edilmesindeki ya da zedelenmesindeki rolü siyasal katılma üzerinden irdelenmektedir. Diğer yandan 18 farklı kamuoyu araştırma şirketinin son dokuz seçimde açıladığı araştırma sonuçları ile seçim sonuçları arasındaki oransal benzerlikler ve farklılıklar tespit edilerek araştırmaların tutarlılığı sınanmaktadır. Kamuoyu araştırma sonuçlarına ulaşmak için retrospektif arşiv tarama tekniğinden yararlanılmıştır. Araştırma sonucunda ORC, KONDA, Metropoll ve A\&G’nin araştırmalarındaki birkaç büyük orandaki hatalı sonuçlar çıkarıldığında bu şirketlerin \%2-3 hata payı ile seçim sonuçlarına yakın araştırma sonuçları yayınladığı tespit edilmiştir. 24 Haziran 2018 Cumhurbaşkanlığı Seçimi’nde 13 şirketin tamamının Recep Tayyip Erdoğan’ın oy oranını kesin seçim sonuçlarından düşük gösterdiği saptanmıştır.

Anahtar Kelimeler: Kamuoyu Araştırmaları, Siyasal Katılma, Tutarlılık, Siyasal Seçimler, Kamuoyu Araştırma Şirketleri, Seçim Sonuçları

\section{Abstract}

Significant differences between some public opinion polls and election results lead citizens to question the credibility of public opinion polls. This study questions public opinion polls conducted for the elections and their relation to media and political participation during the 2010s. This study compares

Arş. Gör. Dr., Gaziantep Üniversitesi, İletişim Fakültesi, Gaziantep, Türkiye, oguzgoxsu@gmail.com. 
the results of the final election with the results of the research of 18 different public opinion poll companies in the last nine elections. Additionally, this study examines the role of public opinion polls about elections in political processes, whether they are building confidence or damaging it through political participation. On the other hand, the reliability of the research is tested by determining the proportional similarities and differences between the results of the poll of 18 different public opinion poll companies in the last nine elections and the election results. Retrospective (backward) archival scanning techniques were used to reach public opinion results for the elections. As a result of research, it is concluded that ORC, KONDA, Metropoll, and A\&G have declared a number of major erroneous results in their attempts. However, it was observed that these companies announced proximate results with 2-3\% error margin. In the Presidential Election which was held in June 24, 2015, it was determined that the total number of the 13 companies denoted Recep Tayyip Erdoğan's vote rate lower than the final election results.

Keywords: Public Opinion Polls, Political Participation, Consistency, Election, Public Opinion Polls Companies, Election Results

\section{Giriş}

Kamuoyu araştırmaları toplumun belirli konulardaki fikir ve eğilimlerini tespit etmeyi amaçlamaktadır (Atabek, 2003, s. 1; Kışlalı, 2010, s. 203). Bu araştırmalar, kamuoyunu temsil etmek üzere seçilen bir örnek grubu oluşturan kişilerin görüşleri alınarak eğilimlerin, kanaatlerin veya çoğu zaman tutum ve davranışların tespiti amacıyla yapılan araştırmalar şeklinde tanımlanmaktadır (Tufan, 1995, s. 11; Le Bon, 2013, s. 6; Güz, 2005, s. 187). Kamuoyu araştırması, zamanın bir bölümündeki tutum, davranış, düşünce, nitelik ile ilişkilerin tüm etkenlerinin ve unsurlarının ölçümlenmesidir. Bu araştırmalardaki en hayati nokta, bilginin kontrollü bir biçimde bilimsel olarak elde edilmesidir (Çoymak, Gheorghiu, Niens ve Lyons, 2015, s. 264).

Seçmenlerin tutum ve kanaatlerini ölçen, ekonomik, toplumsal ve siyasal gelişmeler hakkında toplumun büyük çoğunluğunun görüşlerini ortaya koyan ve doğrudan seçim sonuçlarını öngörmeyi amaçlayan seçimlere yönelik kamuoyu araştırmaları yapılmaktadır. Kamuoyu araştırmaları sadece seçim dönemlerinde değil, siyasal partilerin, üniversitelerin, vakıfların ve enstitülerin istekleri ve çalışmaları doğrultusunda farklı zamanlarda da yapılmaktadır. Bu talebe bağlı olarak, Türkiyede özellikle son yıllarda kamuoyu araştırma şirketlerinin sayısında ciddi oranda artış yaşanmıştır. Bir seçim ülkesi olarak Türkiyede kamuoyu araştırmaları bilhassa seçim kampanyaları döneminde yoğunluk kazanmaktadır. Siyasal iletişim sürecinin bir parçası olarak değerlendirilebilecek kamuoyu araştırmalarının sonuçları bağlamında seçmenleri yönlendirmede kullanıldığı yaygın bir kanaattir. Ancak bu kanaati ya da iddiayı destekleyen veya reddeden bilimsel araştırmalar son derece yetersizdir.

Kamuoyu araştırmalarının kökeni piyasa araştırmaları, basın anketleri ve matematik olasılık yasalarıyla örneklemlerin insan davranışlarına uygulanmasında yatmaktadır. Kamuoyu araştırmalarının artmasındaki en önemli etken daha güvenilir bilgi alma isteğidir. Piyasa 
araştırmalarıyla doğru orantılı olarak kamuoyu araştırmaları da markaların kampanyalarının ve seçim kampanyalarının profesyonelleşmesinden ciddi şekilde etkilenmiştir. Kamuoyu araştırmalarının öncüsü olarak ilk piyasa araştırmaları ve analizleri 1879'da Amerika Birleşik Devletleri’nde $(\mathrm{ABD})$ yapılmışırır. Biçerdöver makinaları üreten bir işletme, hasatlarla ilgili istatistikler toplamış ve gazetelerde çıkan reklamları inceletmiştir. Bununla birlikte, ticari kuruluşlar için olduğu gibi siyasal çevreler için de güvenilir bilgi almak son derece önemlidir (Abadan Unat, 1988, s. 31, 46). Piyasa ve pazar araştırmaları ticari kuruluşlar, şirketler ve markalar için yapılmaktadır. Ürünlerin, hizmetlerin, markaların ve şirketlerin beğenilme düzeyleri, nasıl algılandıkları ve müssterilerin beklentileri piyasa ve pazar araştırmalarıyla tespit edilmektedir.

Türkiye’nin en eski piyasa araştırma şirketi 15 Nisan 1961'de Dr. Nezih H. Neyzi tarafından kurulan Piyasa Etüd Müşavirlik Araştırma Ltd. Şirketiddir (PEVA). Sonrasında, 1975’te PİAR ve ardından 1983'te SİAR kurulmuştur. SİAR farklı konularda önemli kamuoyu araştırmaları yapmıştır. Anavatan Partisi (ANAP) ve Sosyal Demokrasi Partisi (SODEP) SİAR’n müşterileri arasında yer almaktadır. SİAR bu siyasal partiler için kamuoyu araştırmaları gerçekleştirmiştir (Abadan Unat, 1988, s. 38). Dünyada seçimlere yönelik kamuoyu araştırmalarının ilki ise 1936 yılında ABD başkanlık seçimlerinde yapılmıştır. Seçim kampanyası sürecinde George Gallup, bilimsel bir temele bağlı olarak 3000 kişilik bir örneklemle yaptı̆̆ 1 araştırmada beklentilerin aksini iddia ederek Roosevelt' in kazanacağını belirtmiş ve seçim sonucunu bilmiştir. Bu nedenle araştırma, seçimlere yönelik olarak yapılan ilk kamuoyu araştırması olarak görülmektedir (ESOMAR, 2006, s. 5). Türkiye'de ise ilk kez 14 Ekim 1973 genel seçimlerinde Milliyet ve Hürriyet gazeteleri kendi personeline belli bir eğitim verdikten sonra seçimlere yönelik kamuoyu araştırması yaptırarak bu çalışmanın sonuçlarına sayfalarında yer vermiştir. Ancak bu araştırma sonuçlarıyla kesin seçim sonuçları arasında çok büyük farklar oluşmuştur. Böylece seçimlere yönelik kamuoyu araştırmalarının medyayla ve siyasal katılmayla ilişkisi de başlamıştır. Ancak, araştırmaların metodolojik özellikleriyle ilgili önemli bilgilere yer verilmemiştir.

Kamuoyu araştırmalarıyla ilgili çalı̧̧malar incelendiğinde, E. Fazıl Çöllü’nün (2014) araştırmasında güvenilirlik sorununda örneklem hataları, kullanılan göstergelerin geçerliliği, araştırma tekniği ve anketör hataları ön plana çıkmaktadır. Şükrü Balcı ve Bünyamin Ayhan’n (2004) 2004'te gerçekleşen yerel seçim sonuçlarıyla araştırma şirketlerinin gazetelerde yayınlanan kamuoyu araştırma sonuçlarını karşılaştırdığı çalışmasının sonucunda ise, şirketlerin öngörüleriyle seçim sonuçları arasında çok ciddi bir fark ortaya çıkmıştır. Araştırma şirketlerinin bazı siyasi partilere yönelik tahminleri kısmen tutarlı olsa da A\&G, ANAR ve Pollmark'ın Milliyetçi Hareket Partisi (MHP) ve Doğru Yol Partisi’nin (DYP) oy oranlarına ilişkin öngörülerinde önemli sapmalar tespit edilmiştir.

$\mathrm{Bu}$ araştırma, seçimlere yönelik kamuoyu araştırmalarının seçim sonuçlarını tahmin etmedeki başarısını ortaya koyması açısından önem taşımaktadır. 18 farklı kamuoyu araştırma şirketinin 2010-2018 döneminde yapılan son dokuz seçimde seçimlerden önce açılanan son araştırma sonuçlarıyla kesin sonuçları karşılaştırması bakımından bu araştırma alandaki önemli bir boşluğu doldurmakta ve bütüncül bir tablo çizmektedir. Kamuoyu araştırmaları konusunda yapılan akademik çalışmalar kamuoyu araştırmalarının geçerliliğini ve güvenilirliğini sorgularken 
bu çalışmada, araştırma sonuçlarıyla seçim sonuçları karşılaştırılarak araştırmaların tutarlılı̆̆ı irdelenmektedir.

Çalışmada, "Seçimlere yönelik kamuoyu araştırmalarıyla kesin seçim sonuçları arasındaki oransal farklar nelerdir?” sorusuna yanıt aranmaktadır. Çalışmanın amacı, seçimlere yönelik kamuoyu araştırma sonuçlarıyla Yüksek Seçim Kurulu’nun (YSK) açıkladığı kesin seçim sonuçları arasındaki farkları tespit etmek ve bu durumun siyasal katılmayla ilişkisini sorgulamaktır. $\mathrm{Bu}$ noktada, sonuçların tutarlılı̆̆ ya da tutarsızlı̆̆ı üzerinden seçmenlerin kamuoyu araştırmalarına yaklaşımı siyasal katılma bağlamında literatürdeki tartışmalar ışı̆̆ında incelenmektedir. Kamuoyu araştırmalarının başarısı/başarısızlığı inandırıcılık anlamında kesin seçim sonuçları ile seçimlere yönelik kamuoyu araştırmalarının sonuçları arasındaki fark üzerinden sınanmaktadır.

Çalışma, seçimlere yönelik kamuoyu araştırmasıyapan şirketler üzerinden gerçekleştirilmiştir. Kamuoyu araştırma şirketleri seçim dönemlerinde ve öncesinde çok sayıda saha çalışması yapmaktadır. Bu çalışmada, araştırma şirketlerinin seçimlerden hemen önce yaptığı son kamuoyu araştırmaları değerlendirmeye alınmıştır. Kronolojik olarak Türkiyedde yapılan son dokuz seçim araştırmaya dahil edilmiştir. Ele alınan seçimler şunlardır: 24 Haziran 2018 Genel Seçimleri, 24 Haziran 2018 Cumhurbaşkanlığı Seçimi, 16 Nisan 2017 Anayasa Referandumu, 1 Kasım 2015 Genel Seçimleri, 7 Haziran 2015 Genel Seçimleri, 10 Ağustos 2014 Cumhurbaşkanlığ Seçimi, 30 Mart 2014 Yerel Seçimleri, 22 Haziran 2011 Genel Seçimleri ve 12 Eylül 2010 Anayasa Değişikliği Referandumu. Araştırma safhasında kesin seçim sonuçlarına ve kamuoyu araştırmalarının sonuçlarına internet üzerinden ulaşılmıştır. Seçimlere yönelik kamuoyu araştırma sonuçlarına ulaşmak için retrospektif (geriye doğru) arşiv tarama tekniğinden yararlanılmıştır. Araştırmada seçimlerle ilgili bilimsel araştırmalar yapan düşünce kuruluşlarının, üniversitelerin ve vakıfların yaptığı kamuoyu araştırmaları ticari kuruluşlar olmaması nedeniyle çalışmanın dışında tutulmuştur. Kamuoyu araştırmalarının yurt içinde yapılması sebebiyle kesin seçim sonuçlarıla karşılaştırılması açısından kesin seçim sonuçlarının yurt içindeki oy oranları kriter olarak alınmıştır.

\section{Siyasal Katılma ve Oy Verme Davranışı}

Siyaset felsefesi açısından demokrasi ve siyasal katılma birbirini destekleyen ve tamamlayan kavramlardır (Dahlgren, 2014, s. 61). Siyasal katılmanın gerçekleşmesinde farklı etmenler rol oynamaktadır. Kişilerin eğitim durumu, mesleği, yaşı ve geliri yalnızca oy kullanma açısından değil, diğer tüm siyasal katılma boyutlarında kişileri daha aktif olmaya itmektedir (Kapani, 2013, s. 146). Siyasal katılma konusunda bu olguyu etkileyen dinamiklerin tamamı siyasal katılmayı uyarıcı şekilde olumlu bir etkide bulunamaz. Siyasal katılmayı psikolojik açıdan negatif yönde etkileyen faktörler de vardır. Siyasal yabancılaşma ve antipati, siyasal katılmayı negatif yönde etkileyen psikolojik unsurlardır (Turan, 1976, s. 88; Özbudun ve Hale, 2010, s. 100-101). Siyasal katılma yalnızca seçim dönemlerinde oy verme fiilinden ibaret olmayıp, ülke için alınan siyasal kararlara katılmayı da içermektedir. Bireyler dilekçe, toplu dilekçe, milletvekilleriyle yüz yüze görüşme, telefon etme, mektup yazma, e-mail gönderme işlemlerini gerçekleştirmektedir. Bunun 
yanında bireyler, bürokrasiye ise grev, boykot, yürüyüş ve gösteri gibi yollarla etkide bulunmakta, seçimler arasındaki dönemlerde ise siyasal kararların alınmasına katkı sağlamaktadır. Son kertede siyasal katılımı, seçim günlerinde gösterilen bir davranı̧̧ olarak algılamak son derece yanlıştır (Özbudun, Kalaycıŏlu ve Köker, 1995, s. 46; Champagne, 1995, s. 144).

Siyasal katılmada seçmen davranışındaki duygusallık boyutu belirleyici bir unsurdur. Seçmenlerin davranışlarının kökeninde kaygı ve coşku duyguları bulunmaktadır. Coşkuların seçmen tercihini doğrudan kaygıların ise, seçmen kitlesine ve psikolojik değişkenlere göre dolaylı biçimde etkilediği savunulmaktadır. Vatandaşlar ilgi alanlarına göre siyasal konular ve dünya görüşü farklılıklarına paralel olarak siyasal tartışmaların içine girmektedirler (Marcus ve Mackuen, 1993, s. 677; Kalender, 2005, s. 57; Özkan, 2007, s. 189).

1940'lı yıllarda Columbia Uygulamalı Sosyal Araştırmalar Bürosu tarafından seçmenlerin oy verme davranışı ve seçim kampanyalarıyla ilgili önemli araştırmalar gerçekleştirilmiştir. 1940 ABD Başkanlık Seçimlerinde Ohio’nun Erie bölgesinde yapılan çalışmada amaç, seçmenlerin oy verme davranışında kitle iletişim araçlarının gücünü belirlemektir. Bu araştırmada Paul F. Lazarsfeld ve arkadaşları bireysel ilişkilerin oy verme davranışı üzerinde kitle iletişim araçlarından daha etkili olduğu sonucuna ulaşmıştır. Erie araştırmasında iki aşamalı akış modeli geliştirilmiştir. Buna göre, kitle iletişim araçları tarafından iletilen mesajların önce kanaat önderlerine, kanaat önderlerinden de yakın çevrelerine ulaştığ 1 iddia edilmektedir. 1948'de ABD Başkanlık Seçimleri dolayısıyla New York’un Elmira bölgesinde yapılan diğer bir araştırmada, seçim kampanyası süresince kitle iletişim araçlarının nasıl bir rolü olduğu belirlenmeye çalışılmıştır. Bernard R. Berelson ve arkadaşları, araştırma sonucunda bireylerin kendi fikirleriyle aynı doğrultuda haberleri takip ettiği ve ayrıca kitle iletişim araçlarının seçmenlerin önceden sahip olduğu görüşleri daha da güçlendirdiği sonucuna ulaşmıştır. Özetle, kitle iletişim araçlarının insanların görüşleri ve oy tercihleri üzerinde önemli bir etkisi olmadığı sonucuna ulaşılmıştır (Akt. Güngör, 2013, s. 101). Seçmenlerin zihinleri, kamuoyu araştırma sonuçlarının yüzdelerinin girilerek çeşitli karşılaştırmalarla çıktı alınacak ve buna bağlı olarak oy tercihini yapacak bir işletim sistemi değildir. Vatandaşların kamuoyu araştırma sonuçlarına tam olarak nasıl karşıllık vereceği net olarak tespit edilememiştir. Seçmenler çoğunlukla kamuoyu araştırma sonuçlarına farklı tepkiler vermektedir. Vatandaşların oy verme davranışında, kaynağın güvenilirliği, kişinin siyasi sempatisi, bireylerin geçmişi, ailesi, çevresi, işi ve huyları birleşerek şahsi kararı ortaya çıartmaktadır (Esomar, 2006, s. 3).

\section{Seçimlere Yönelik Kamuoyu Araştırmaları}

Münci Kapani kamuoyu kavramını "Kamuoyu, belli bir zamanda belli bir tartışmalı sorun karşısında, bu sorunlarla ilgilenen kişiler grubuna veya gruplarına hakim olan kanaattir” şeklinde tanımlamıştır. Kamuoyu içinde "hakim kanaatin" nasıl ortaya çıktığı kamuoyunun oluşumunu anlamada belirleyici unsurdur. Bu noktada iki önemli faktör bulunmaktadır. Bunlardan birincisi çoğunluk faktörü, başka bir deyişle, sayı unsurudur. Bir açıdan bakıldığında kamuoyu çoğunluğun kanaatidir. Fakat bazı özel durumlarda çoğunluk olmak geçersizleşmektedir. Yoğunluk ya da 
etkinlik unsurları kesin ve köklü bir şekilde ifade edildiğinde bu görüş azınlığın kanaati bile olsa çoğunluğun zayıf ve köksüz olarak paylaşılan görüşü karşısında baskın ve üstün gelmektedir (Kapani, 2013, s. 161-162; Abadan Unat, 1988, s. 34). ABD başkanlarından Abraham Lincoln, "Kamuoyu her şeydir; kamuoyuna dayanan hiçbir şey başarısız olmaz, kamuoyuna dayanmayan hiçbir şey de başarı kazanamaz.” şeklinde görüşlerini bildirmiştir (Akt. Meray, 1954, s. 258).

Seçim sonuçlarına yönelik araştırmaları özellikle seçimlere iki ay kala yoğunlaşmakta ve medyada farklı gazeteler, televizyon kanalları ve internet sitelerinde yayınlanmakta ve hatta gündem oluşturmaktadır. Seçim kampanyaları süresince siyasal parti liderleri katıldıkları televizyon programlarında ve verdikleri röportajlarda kendilerinin yaptırdığı son anket sonuçlarını kamuoyu ile paylaşarak partilerinin son durumlarını ortaya koymaktadır. Ancak liderlerin paylaştığı bu sonuçlara bakıldığında, kendi partilerinin daima yükseliş trendinde olduğu ya da oylarını artırdığı araştırma sonuçlarının medyaya yansıdığı görülmektedir.

Avrupa Konseyi Parlamenterler Meclisi medyada yer alan kamuoyu araştırma sonuçları ile seçmenlerin siyasal parti tercihleri arasında nasıl bir ilişki olduğunu incelemiştir. Parlamento ve Parlamentonun Halkla İlişkiler Komisyonu, Avrupa Konseyỉne üye olan bazı ülkeler ve demokratik rejimleri benimsemiş ülkelerde bu konuyla alakalı olarak şu değerlendirmeleri yapmıştır:

- Kamuoyu araştırmalarının seçim sonuçlarını etkilediği şeklindeki tüm deliller nesnellikten uzaktır.

- Kamuoyu araştırması sonuçlarına göre siyasal partiler seçim kampanyası süresince farklı konuları öne çıkarmalarına karşın, kamuoyu araştırması sonuçlarının medya aracilığıyla doğru biçimde yayınlanmasının seçim sonuçlarında ciddi bir etkisi yoktur.

- Seçimlerde vatandaşlar oyları gizli şekilde kullanmaları nedeniyle kamuoyu araştırmalarıyla seçim sonuçlarına etki edildiğiyle alakalı net kanıtlar yoktur.

- Gerçek kamuoyu araştırmalarının objektif bir şekilde yayınlanmasının, sonuç üzerinde güçlü ve fark edilebilir bir etkisi olmamıştır (ESOMAR, 2006, s. 3).

Kamuoyu araştırmalarının diğer boyutunda siyasetçiler yer almaktadır. Politikacılar bilimsel ve güvenilir kamuoyu araştırmalarının sonuçlarını kritik kararlarında ve politikalarında dikkate almaktadır. Bu nedenle kamuoyu araştırmalarının halkın dışında siyasiler üzerinde kısmen etkili olduğu söylenebilir. Siyasal partiler, milletvekilleri, belediye başkan adayları ve aday adayları seçim kampanyası stratejilerini ve taktiklerini belirlemek için kamuoyu araştırmalarına başvurmaktadırlar (Güngör, 2013, s. 105; Sezgin, 2003, s. 57).

\section{Kamuoyu Araştırmalarının Seçmenler Üzerindeki Etkileri}

Kamuoyu araştırmalarının toplum üzerindeki etkileriyle ilgili fikirler üç grup halinde ifade edilmektedir:

- Araştırma sonuçlarının önemli bir etkisinin olmadığı ve bu etkinin gereğinden fazla büyütüldügü görüşünde olanlar, 
- Kamuoyu araştırmalarının toplumu ihtiyaç ve taleplerini yansıttığını ve temsili demokrasiye hizmet ettiği savunanlar,

- Kamuoyu araştırmalarının toplumun fikirlerini çeşitli şekillerde yansitıyor gibi görünse de aslında yerleşik egemen fikirlerin işine yaradığını düşünenler (Özerkan, 1992, s. 61 - 82).

Siyasal iletişim sürecinde seçimlerin öncesinde yayınlanan kamuoyu araştırma sonuçlarının seçmenler üzerinde beş farklı etkiye sahip olduğu düşünülmektedir:

Bumerang Etkisi: Kamuoyu araştırma sonuçlarına göre, seçmen kendi desteklediği siyasal partinin ya da adayın ezici bir oranla kazanacağını görmesi üzerine seçimi kaybetmekte olan partinin ya da adayın durumuna bakarak çalışmaları aksatabilir veya oy kullanma zahmetine katlanmayabilir. Ayrıca seçmen rakibin kötü durumda olması nedeniyle onu destekleme davranışını da sergileyebilir.

Yenilmişlik (Kamçılama) Etkisi: İnsanlar zaman zaman sonucu tahmin edilebilir seçimlerde bir tarafın bariz şekilde kazanmasını istemeyebilirler. Buna bağlı olarak da seçmenler önde olan siyasal parti ya da adayı göz ardı ederek geride olan tarafı destekleyebilir. Bu nedenle kamuoyu araştırmalarının sonuçlarına göre zayıf durumda olan siyasal parti ya da adayın desteklenmesi eğilimi ortaya çıkabilir.

Gözde Taraf Etkisi (Bandwagon Etkisi): Bireyler genel olarak kazanan tarafta olmak isterler. Buna bağlı olarak özellikle kararsız seçmen kamuoyu araştırma sonuçlarına bakarak önde olan siyasal parti ya da adaydan yana tavır alabilir. Ancak burada kritik nokta seçmenlerin bu kamuoyu araştırma sonuçlarını takip ederek incelemesidir.

Toparlanma Etkisi: Seçime katılan küçük siyasal partiler kamuoyu araştırma sonuçlarına göre oy oranlarını artırırlarsa bu siyasal partinin seçimleri kazanamayacağı algısıyla diğer siyasal partilere kayan seçmenler yeniden eskiden destekledikleri siyasal partiye yönelebilirler.

Tedbirli Oy Kullanma Etkisi: Seçmenlerin bir kısmı oylarını kamuoyu araştırma sonuçlarını değerlendirdikten sonra kullanmaktadır. Bu noktada seçmen toplumsal çevre tarafından dışlanma tehdidinden kurtulmak için çoğunluğun görüşüne uyar ve oyunu büyük siyasal partiden, başka bir ifadeye araştırma sonuçlarına göre önde gözüken siyasal partiden ya da adaydan yana kullanır (Lazersfeld, Berelson ve Gaudet, 1955, s. 74-75; Kalender, 2005, s. 108-109).

Bu konudaki teorik tartışmalarda önemli bir nokta da şudur: Kamuoyu araştırmalarındaki belli ölçülerdeki yanılgılar sürpriz olarak karşılanmamakta hatta bu tip hatalar beklenmektedir. Çünkü bu durum "oy kullanmanın ve seçimin yerine geçememenin" kanıtı olarak görülmektedir (Champagne, 1995, s. 151). Siyasal partiler, seçimlere yönelik kamuoyu araştırmalarıyla gündem oluşturmaya gayret etmektedir. Bu noktada kararsız seçmenin sandık başına gittiğinde çoğunluktan yana tavır alacağı düşüncesiyle hareket edilmektedir. Medya ve siyasal partiler, güven kazanmak yerine gündem oluşturmayı ve seçmeni baskı altına almayı yeğler gözükmektedir. 


\section{Medyanın Kamuoyu Araştırmalarına Yaklaşımı}

Açıkça yayınlanma ve yorumlanma amacıyla medyanın ısmarladığı kamuoyu araştırmaları vardır. Böylece gazeteciler kendilerini, araştırmalar yoluyla "halkın fikirlerini veya tercihlerini" bilimsel olarak güvence altında ifade eden sözcü konumuna yükseltirler (Champagne, 1995, s. 147). Medyanın kendi kontrolünde yaptırdığı kamuoyu araştırmalarına endişeyle yaklaşılmalı ve vatandaşları yönlendirme olasılığı her zaman dikkate alınmalıdır (Özkan, 2007, s, 189). Gazetecilerin büyük kısmının kamuoyu araştırmalarına yaklaşımı politikacılarla benzerlik göstermektedir. Kamuoyu araştırmaları gazetecilerin doğrudan çıkarlarına ne oranda hizmet ediyorsa gazeteciler de bu araştırmaları o oranda desteklemektedir. Kesin seçim sonuçlarında istediğini bulamayan medya, bu durumda seçmeni "kararsı" ve "yüzer-gezer" olmakla nitelemektedir (Champagne, 1995, s. 144). Bazı medya organları siyasal iktidarla görüş, çıkar ve ideoloji ilişkilerini yayın politikalarına alet etmektedirler. Seçim öncesindeki kamuoyu araştırmalarında siyasal iktidarda olan parti lehine gerçekleri çarpıtan kamuoyu araştırma sonuçlarının yayınlandığı görülmektedir (Özkan, 2007, s.189).

2016 Kasım’ındaki ABD Başkanlık Seçimleri öncesinde Ekim ve Kasım aylarında yapılan 15 kamuoyu araştırmasında Donald Trump’ önde gösteren sadece iki araştırma vardır. Bu iki araştırmada da adayların oy oranları eşit gösterilmiştir. Seçime günler kala açıklanan anketlerin hiçbiri Trump’nn oy oranına \% 4.5 ’ten daha fazla yaklaşamamıştır. Diğer yandan tüm anketlerde Hillary Clinton'ın daha fazla delegeye ulaşarak başkan olacağ $\breve{1}_{1}$ dia edilse de Trump, Clinton'dan az farkla da olsa daha düşük oy almasına karşın kritik eyaletleri kazanıp 270 delegeye ulaşarak seçimi kazanmıştır. Yalnızca bir şirket Trump’ın başkan olacağını öngörmüş, ancak o da oy oranına yakın tahminde bulunamamıştır. Bu 15 araştırmayı gerçekleştirenler arasında Economist, Reuters, Fox News, NBC News, CBS News, Bloomberg ve ABC gibi medya kuruluşlarının da olduğu düşünüldüğünde anketlerin tutarsızlığının yanı sıra medyanın da kamuoyu araştırmalarıyla gündemi ve siyaseti kısmen belirlediği görülmektedir. Konu ABD başkanlık seçimleri olduğu için bu araştırmalar aynı zamanda uluslararası alanda da kendisinden söz ettirmektedir.

\section{Seçimlere Yönelik Kamuoyu Araştırmalarıyla İlgili Yapısal ve Yasal Düzenlemeler}

Medya yukarıda bahsi geçen sonuçlara ciddi bir tiraj, satış ve reyting kaygısıyla yer vermektedir. 1990 sonrasında bazı Avrupa ülkeleri, kamuoyu araştırmalarının uygulanmasını düzenlemeye yönelik kanunlar yapmıştır. Bu kanunlar incelendiğinde kamuoyu araştırma sonuçlarının yayınlanmasının yasaklandığı seçim öncesi dönemlerin olduğu da görülmektedir. $\mathrm{Bu}$ yaklaşım, seçmenlerin aklını karıştırarak onların seçme özgürlüğüne müdahale edebilecek aşırılıklardan korunması gerektiği iddiasını taşımaktadır. Belçika, 1985 yılında bu konuda bir adım atarak seçimlere dört hafta kala kamuoyu araştırmalarının yayınlanmasını yasaklamıştır. Tüm bu eylemler, seçim öncesi kamuoyu araştırmalarının yayınlanmasının kamuoyunu manipüle ettiği varsayımına dayanmaktadır (ESOMAR, 2006, s. 2). Türkiye'de ise kamuoyu araştırmalarının yayınlanmasıyla ilgili 298 sayılı Seçimler Hakkındaki Kanun ve ayrıca YSK’nın 1550 ve 1548 sayılı 
kararları, seçim öncesinde belirli sürelerde seçimlere yönelik kamuoyu araştırma sonuçlarının yayınlanmasını düzenlemektedir. Kanuna göre, seçimden önceki 10 günlük sürede yazıll, sözlü ve görsel basın yayın araçları ile kamuoyu araştırmaları, tahminler, anketler, bilgi ve iletişim yoluyla küçük çaplı oylama ya da referandum gibi adlarla bir siyasal partinin ve adayın lehinde ya da aleyhinde vatandaşların oyunu etkileyecek yayın yapılıp herhangi bir surette dağıtılması yasaklanmıştır.

\section{Amaç ve Yöntem}

Çalışmada, Türkiye'de 2010 sonrasında yapılan seçimlere yönelik kamuoyu araştırmaları ile bu araştırmaların medyayla ve siyasal katılmayla ilişkisi sorgulanmaktadır. Çalışmada, "Seçimlere yönelik kamuoyu araştırmalarıla kesin seçim sonuçları arasındaki oransal farklar nelerdir?” sorusuna yanıt aranmaktadır. Çalışmanın amacı, seçimlere yönelik kamuoyu araştırma sonuçlarıyla YSK'nin açıkladığı kesin seçim sonuçları arasındaki farkları tespit etmek ve bu durumun siyasal katılmayla ilişkisini sorgulamaktır. Bu çalışmada; A\&G, ANAR, GENAR, SONAR, KONDA, Konsensus, Pollmark, Metropoll, ORC, Gezici, Andy-Ar, MAK, Optimar, İVEM, PİAR, REMRES, THEMİS ve AKAM olmak üzere 18 kamuoyu araştırma şirketinin seçimlerin öncesinde açıkladıkları araştırma sonuçlarına yer verilmiştir. Araştırma kapsamında Türkiye yapılan son dokuz seçimdeki seçim sonuçları ile 18 farklı kamuoyu araştırma şirketinin seçimlere yönelik olarak gerçekleştirdiği son kamuoyu araştırma sonuçları karşılaştırılarak seçim sonuçlarına en yakın ve en uzak tahminleri yapan araştırmalar şirketleri tespit edilmiştir. Araştırma kapsamında 12 Eylül 2010 Anayasa Değişikliği Referandumu'nda 'Evet' ve 'Hayır' oy oranları, 12 Haziran 2011 Genel Seçimleri'nde Adalet ve Kalkınma Partisi (AK Parti), Cumhuriyet Halk Partisi (CHP) ve Milliyetçi Hareket Partisi (MHP)'nin oy oranları, 7 Haziran 2015, 1 Kasım 2015 Genel Seçimleri’nde ve 30 Mart 2014 Yerel Seçimleri'nde AK Parti, CHP, MHP ve Barış ve Demokrasi Partisi (BDP)/Halkların Demokratik Partisi (HDP)'nin oy oranları, 10 Ağustos 2014 Cumhurbaşkanlığı Seçimi’nde Recep Tayyip Erdoğan, Ekmeleddin İhsanoğlu ve Selahattin Demirtaşıın oy oranları, 16 Nisan 2017 Anayasa Değişikliği Referandumu’nda 'Evet' ve 'Hayır' oy oranları, 24 Haziran 2018 Genel Seçimleri’nde AK Parti, CHP, İYI Parti (İP), MHP ve HDP’nin oy oranları, 24 Haziran 2018 Cumhurbaşkanlığı Seçimi'nde Doğu Perinçek, Meral Akşener, Muharrem İnce, Recep Tayyip Erdoğan, Selahattin Demirtaş ve Temel Karamollaoğlu’nun oy oranları ve YSK’nin açıkladığı kesin seçim sonuçlarıyla kamuoyu araştırma şirketlerinin seçimlere yönelik açıkladıkları son kamuoyu araştırma sonuçları incelenmiştir.

Ele alınan kamuoyu araştırma şirketlerinin internet siteleri incelenerek seçimlere yönelik kamuoyu araştırma sonuçlarına şeffaflık ilkesi çerçevesinde yer verip vermedikleri belirlenmiştir. Bilimin nedensellik prensibi gereği, seçim sonuçları ile araştırma sonuçları arasında bariz farklar olan şirketlerin bu farkların neden kaynaklandığını ortaya koyan bir çalısma yapıp yapmadıkları incelenmiştir. Çalışmada, retrospektif arşiv tarama tekniği kullanılarak bugünden geriye doğru gidilip internet üzerinden araşıırma sonuçlarına ulaşılmıştır. Bu teknik ağılıklı olarak tıp alanında kullanılmaktadır. Vakalar tek tek kontrol edilerek kayıt altına alınmakta ve genel bir sonuca 
varılmaktadır. Bu teknik, güncel araştırmalara ulaşmak ve siyasetin profesyonelleşmesi bağlamında son dönemde yapılan kamuoyu araştırmalarında bilimsel kriterlere daha fazla uyulduğu varsayımına bağlı olarak tercih edilmiştir. Çalışmada yer alan sonuçlar tutarsız olursa o şirketin açıklayacağ 1 diğer araştırma sonuçlarına da kuşkuyla bakılma ihtimali bu tekniğin zayıf yönüdür.

\section{Bulgular: Kesin Seçim Sonuçlarıyla Seçimlere Yönelik Kamuoyu Araştırma Sonuçlarının Karşılaştırılması}

\section{2 Eylül 2010 Anayasa Değişikliği Referandumu}

12 Eylül2010 Anayasa Değişikliği Referandumunda ANARve ORC’nin kamuoyu araştırmaları medyaya yansımamış ve şirketlerin kendileri de araştırma sonuçlarını internet sitelerinden yayınlamamıştır. Gezici Araştırma Şirketi ise, seçimin yapıldığı tarihte henüz kurulmadığı için çalışma kapsamında bu şirketin araştırma sonuçları Tablo l'de yer almamaktadır.

Bu seçimlere katılım oranı \%73,71 seviyesinde olmuştur. Tablo 1'de kesin seçim sonuçları, kamuoyu araştırma şirketlerinin sonuçları ve bu sonuçlar arasındaki sapma oranları görülmektedir (“İște Referandum’un resmi sonuçları”, 2015; “Bütün anket şirketlerinin”, 2015).

Tablo I: I2 Eylül 20 I0 Anayasa Değişikliği Referandumu Sonuçları ve Kamuoyu Araştırma Sonuçlarının Karşılaştırması

\begin{tabular}{|c|c|c|c|c|c|c|c|c|c|c|c|}
\hline 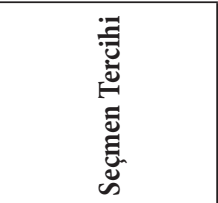 & 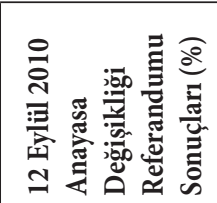 & 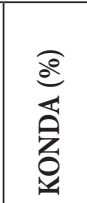 & 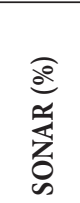 & 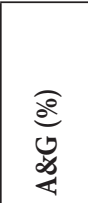 & 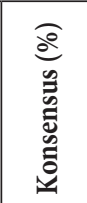 & 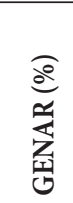 & 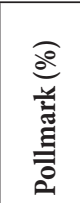 & 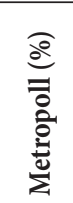 & 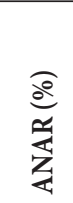 & 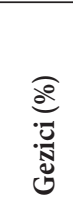 & $\begin{array}{l}\widehat{o} \\
\text { ô } \\
\text { ơ }\end{array}$ \\
\hline Evet & 57,88 & 56,8 & 49,9 & 51 & 55,2 & 56,2 & 56,2 & 59,6 & - & - & - \\
\hline \begin{tabular}{|l|} 
Sapma Oranı $(\%)$ \\
\end{tabular} & & $-1,08$ & $-7,98$ & $-6,88$ & $-2,68$ & $-1,68$ & $-1,38$ & $+1,72$ & & & \\
\hline \begin{tabular}{|l|} 
Hayır \\
\end{tabular} & 42,12 & 43,2 & 50,1 & 49 & 44,8 & 43,8 & 43,8 & 40,4 & - & - & - \\
\hline Sapma Oranı(\%) & & $+1,08$ & $+7,98$ & $+6,88$ & $+2,68$ & $+1,68$ & $+1,68$ & $-1,72$ & & & \\
\hline
\end{tabular}

Anayasa Değişikliği Referandumu’nda KONDA, çok net bir biçimde diğer kamuoyu araştırma şirketlerinden başarılı bir kamuoyu araştırması gerçekleştirmiş ve referandum sonucunu \%1,08 fark ile tespit etmiştir. SONAR’ın kamuoyu araştırması ise, referandum sonuçlarından en farklı oranları vermiştir. Referandumda araştırma sonuçları incelenen 7 şirketin 6’sının 'Evet' oylarını düşük, 'Hayır' oylarını ise yüksek gösterdiği belirlenmiştir.

\section{2 Haziran 20 I | Genel Seçimleri}

Bu seçimde kesin seçim sonuçları ile AK Parti, CHP ve MHP’nin oy oranlarını gösteren kamuoyu araştırmaları ele alınmıştır. 12 Haziran 2011 Genel Seçimleri’nde BDP seçimlere siyasal parti olarak girmek yerine bağımsız adaylar göstererek seçime katılmayı tercih etmiştir. Ele alınan kamuoyu araştırma şirketlerinin bazıları bağımsız adayların bazıları ise, BDP’nin oy 
oranını açılamıştır. YSK ise resmi olarak bağımsız adayların oy oranını ilan etmiştir. Ancak bu oranların ne kadarının BDP’nin bağımsız adaylarına ait olduğunun bilinmemesi sebebiyle BDP’nin ya da bağımsız adayların oy oranlarına yer verilmemiştir. Ayrıca 2011 yılında kurulan Gezici Araştırma Şirketi bu seçimlerde kamuoyu araştırması gerçekleştirmediği için bu şirketin araştırma sonuçları Tablo 2'de yer almamıştır.

Bu seçimlerde katılım oran1 \%87,16 seviyesinde olmuştur. Tablo 2'de kesin seçim sonuçları, kamuoyu araştırma şirketlerinin sonuçları ve bu sonuçlar arasındaki sapma oranları görülmektedir (“Seçimi hangi anket şirketi”, 2011; “İște ORC’nin son”, 2015).

Tablo 2: I 2 Haziran 20 I I Genel Seçim Sonuçları ve Kamuoyu Araştırma Sonuçlarının Karşılaştırması

\begin{tabular}{|c|c|c|c|c|c|c|c|c|c|c|c|}
\hline 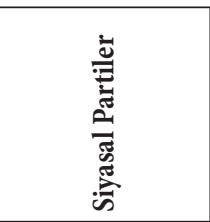 & 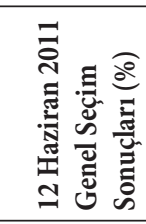 & 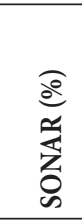 & 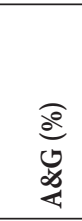 & 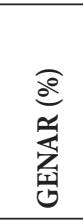 & 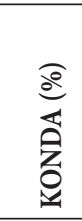 & 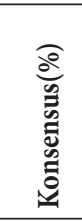 & 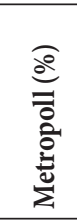 & 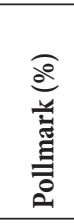 & 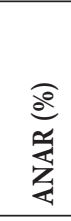 & $\begin{array}{c}\widehat{o} \\
\text { ơ } \\
\text { o }\end{array}$ & 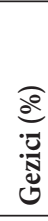 \\
\hline AK Parti & 49,80 & 51 & 48 & 47,7 & 46,5 & 48 & 42 & 47,4 & 46 & 53,6 & - \\
\hline Sapma Oranı(\%) & & $+1,12$ & $-1,8$ & $-2,1$ & $-3,3$ & $-1,8$ & $-7,8$ & $-2,4$ & $-3,2$ & $+3,8$ & \\
\hline CHP & 25,98 & 25,78 & 29 & 26,2 & 26,8 & 27 & 29 & 25,2 & 26 & 21,7 & - \\
\hline Sapma Oranı(\%) & & $-0,2$ & $+3,02$ & $+0,22$ & $+0,82$ & $+1,02$ & $+3,02$ & $-0,78$ & $-0,02$ & $-4,28$ & \\
\hline MHP & 13,02 & 12,45 & 13 & 13,8 & 10,8 & 12 & 15 & 12,6 & 12 & 11,5 & - \\
\hline Sapma Oranı(\%) & & 0,57 & $-0,02$ & $+0,78$ & $-2,22$ & $-1,02$ & $+1,98$ & $-0,42$ & $-1,02$ & $-1,52$ & \\
\hline
\end{tabular}

2011 Genel Seçimlerinde AK Parti’nin oy oranına en yakın sonuca \%1,12 fark ile SONAR, CHP'nin oy oranına en yakın sonuca \%0,02 ile ANAR, MHP'nin oy oranına en yakın sonuca \%0,02 ile $\mathrm{A} \& \mathrm{G}$ ulaşmıştır. Bu seçimde Tablo 2'de belirtilen 3 siyasal partinin oy oranlarına ilişkin araştırma sonuçlarındaki sapma oranlarına bakıldığında en başarılı araştırma sonuçlarına SONAR, en başarısız sonuçlara ise Metropoll tarafından ulaşıldığı belirlenmiştir.

\section{Mart 20 I 4 Yerel Seçimleri}

Yerel seçimlerde en önemli faktör siyasal partilerin ön planda olduğu belediye meclis üyeliği seçim sonuçlarıdır. Yerel seçimlerde ağırlıklı olarak yerel nitelikler ve adaylar belirleyici olmaktadır. Yerel seçimlerde genel seçimlerden, cumhurbaşkanlığı seçimlerinden ve referandumdan farklı olarak seçmenler, belediye başkanlığı, il genel meclis üyeliği ve belediye meclis üyeliği için oy kullanmaktadır. Bu nedenle kamuoyu araştırmalarında yerel seçimler için ağırlıklı olarak "seçmenlerin siyasal parti tercihi" sorgulanmaktadır. Ayrıca bazı kamuoyu araştırma şirketleri önemli büyükşehirlerde seçmenlerin hangi partinin büyükşehir belediye başkan adayını tercih edeceği yönünde araştırmalar da yapmaktadır. Bu seçimdeki diğer önemli nokta, seçimlerden önce BDP’nin Türkiye’nin batısında HDP adıyla seçimlere girmesi olmuştur. Kamuoyu araştırma şirketleri araştırmalarında BDP/HDP ayrımı yapmadan oy oranlarını BDP endeksli olarak açıklamıştır. Bu nedenle Tablo 3’te yer alan oranlarda BDP’nin 
\%4,16 ve HDP'nin \%2,12'lik oy oranları toplanarak \%6,28'lik toplam oy oranı ile kesin seçim sonuçları karşılaştırılmıştır.

30 Mart 2014 Yerel Seçimleri’nde Türkiye’deki nüfusun en geniş şekilde temsil edildiği ve en fazla kayıtlı seçmenin bulunduğu belediye meclis üyeliği seçim sonuçları kriter olarak alınarak bu seçim sonuçları ile kamuoyu araştırma sonuçları karşılaştırılmıştır. Seçimin yapıldığı tarihte belediye meclis üyeliği seçimlerde 48.8 milyonun üzerinde kayıtlı seçmen vardır. Katılım oranının \%89.15 seviyesinde olduğu seçimlerde belediye meclis üyeliği seçim sonuçları ile kamuoyu araştırma sonuçları arasındaki sapma oranları Tablo 3’te görülmektedir (“30 Mart 2014 Yerel”, 2014; “ Türkiye Geneli Sonuçları”, 2014; “4 farklı araştırma şirketi”, 2015; "Seçime haftalar kala”, 2015; "SONAR ve GENAR seçim anketi”, 2014).

Tablo 3: 30 Mart 20।4 Yerel Seçim Sonuçları ve Kamuoyu Araştırma Sonuçlarının Karşılaştırması

\begin{tabular}{|c|c|c|c|c|c|c|c|c|c|c|c|}
\hline Siyasal Partiler & $\begin{array}{l}\text { Belediye Meclis } \\
\text { Üyeliği Seçim } \\
\text { Sonuçları (\%) }\end{array}$ & 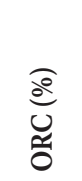 & $\begin{array}{l}\widehat{o} \\
\text { ô } \\
0 \\
0\end{array}$ & 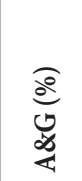 & $\frac{\widehat{e}}{\frac{a}{z}}$ & 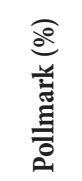 & 高 & 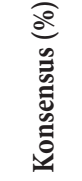 & $\frac{\widehat{o}}{a}$ & 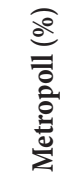 & 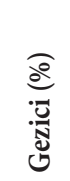 \\
\hline AK Parti & $\% 42,87$ & 45,7 & 46 & 44 & 46,9 & 49,4 & 48,8 & 41,7 & 42,3 & 36,3 & 39,9 \\
\hline Sapma Oranı(\%) & & $+2,83$ & $+3,13$ & $+1,13$ & $+4,03$ & $+6,53$ & $+5,93$ & $-1,17$ & $-0,57$ & $-6,57$ & $-2,97$ \\
\hline CHP & $\% 26,34$ & 28,3 & 27 & 26,5 & 30,1 & 28,3 & 28 & 29,5 & 29,8 & 28 & 31,3 \\
\hline Sapma Oranı(\%) & & $+1,43$ & $+0,66$ & $+0,16$ & $+3,76$ & $+1,96$ & $+1,66$ & $+3,16$ & $+3,46$ & $+1,66$ & $+4,96$ \\
\hline MHP & $\% 17,82$ & 16 & 15 & 15 & 14,3 & 13,2 & 13 & 15,4 & 18,7 & 14,6 & 19,2 \\
\hline Sapma Oranı(\%) & & $-1,82$ & $-2,82$ & $-2,82$ & $-3,52$ & $-4,62$ & $-4,82$ & $-2,42$ & $+0,88$ & $-3,22$ & $+1,38$ \\
\hline BDP/HDP & $\% 6,28$ & 6 & 7 & 9,5 & 5,8 & 6,2 & 6,5 & 6,5 & 5,6 & 6,7 & 7,8 \\
\hline Sapma Oranı(\%) & & $-0,28$ & $+0,72$ & $+3,22$ & $-0,48$ & $-0,08$ & $+0,22$ & $+0,22$ & $-0,68$ & $+0,42$ & $+1,52$ \\
\hline
\end{tabular}

2011 Genel Seçimlerinde olduğu gibi yerel seçimlerde de en fazla sapma oranlarının AK Parti’nin oy oranlarında olduğu görülmektedir. A\&G dışındaki diğer 9 araştırma şirketinin sonuçlarıyla BDP/HDP’nin oy oranları arasında tutarlılık olduğu sonucuna varılmıştır. Yerel seçimlerde AK Parti'nin oy oranına en yakın sonuca \%0,57 fark ile SONAR, CHP'nin oy oranına en yakın sonuca \%0,16 fark ile A\&G, MHP’nin oy oranına en yakın sonuca \%0,88 fark ile SONAR ve BDP/HDP’nin oy oranına en yakın sonuca \%0,08 ile Pollmark ulaşmıştır. 10 araştırmanın tamamında CHP’nin oy oranı kesin seçim sonuçlarından daha yüksek seviyede gösterildiği dikkat çekmektedir.

\section{0 Ağustos 2014 Cumhurbaşkanlığı Seçimi}

Cumhurbaşkanlığı seçiminde seçime katılım oranı \%73,2 olmuştur. Tablo 4’te kesin seçim sonuçları, kamuoyu araştırma şirketlerinin sonuçları ve bu sonuçlar arasındaki sapma oranları görülmektedir (“6 şirketin Cumhurbaşkanı”, 2015; “Temmuz ayında Cumhurbaşkanlığı”, 2014). 
Tablo 4: 10 Ağustos 2014 Cumhurbaşkanlığı Seçim Sonuçları ve Kamuoyu Araştırma Sonuçlarının Karşılaştırması

\begin{tabular}{|c|c|c|c|c|c|c|c|c|c|c|c|}
\hline 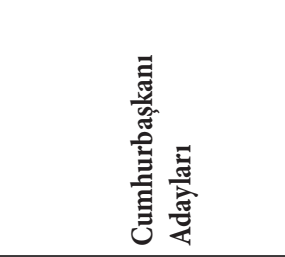 & 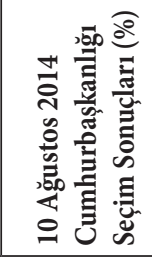 & 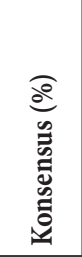 & 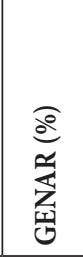 & 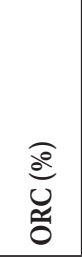 & 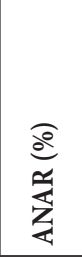 & $\begin{array}{l}\widehat{a} \\
\text { os } \\
\text { zo } \\
\text { on }\end{array}$ & 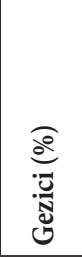 & 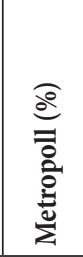 & 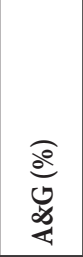 & 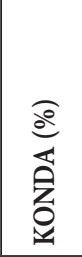 & 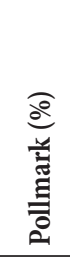 \\
\hline Recep Tayyip Erdoğan & $\% 51,79$ & 58,2 & 55,2 & 54,6 & 54,5 & 52,6 & 55,3 & 42 & 55,1 & 57 & 51,4 \\
\hline Sapma Oranı (\%) & & $+6,41$ & $+3,41$ & $+2,81$ & $+2,71$ & $+0,81$ & $+3,51$ & $-9,79$ & $+3,31$ & $+5,21$ & $-0,39$ \\
\hline Ekmeleddin İhsanoğlu & $\% 38,44$ & 30,3 & 35,8 & 37 & 36,5 & 40,3 & 34,6 & 33 & 33,3 & 34 & 37,9 \\
\hline Sapma Oranı (\%) & & $-8,14$ & $-2,64$ & $-1,44$ & $-1,94$ & $+1,86$ & $-3,84$ & $-5,44$ & $-5,14$ & $-4,44$ & $-0,54$ \\
\hline Selahattin Demirtaş & $\% 9,76$ & 11,5 & 8 & 8,4 & 7,5 & 7,1 & 10,1 & 6,7 & 11,6 & 9 & 7,2 \\
\hline Sapma Oranı (\%) & & $+1,74$ & $-1,76$ & $-1,36$ & $-2,26$ & $-2,66$ & $+0,34$ & $-3,06$ & $+1,84$ & $-0,76$ & $-2,56$ \\
\hline
\end{tabular}

Cumhurbaşkanlığı seçiminde Erdoğan'ın ve İhsanoğlu'nun oy oranına en yakın sonuçlara \%0,39 ve \%0,54 farkla Pollmark, Selahattin Demirtaş'ın oy oranına en yakın sonuca \%0,34 farkla Gezici Araştırma şirketi ulaşmıştır. Bu seçimlerde kamuoyu araştırmalarının Demirtaş’ın oy oranına yaklaşma seviyesi Erdoğan ve İhsanoğlu’ndan açık şekilde daha fazla olduğu görülmektedir.

\section{Haziran 20 I5 Genel Seçimleri}

Katılım oranının \%83,92 olduğu seçimlerde meclise giren dört parti de tek başına iktidar olabilecek milletvekili sayısına ulaşamamıştır. Tablo 5’te kesin seçim sonuçları, kamuoyu araştırma şirketlerinin sonuçları ve bu sonuçlar arasındaki sapma oranları görülmektedir ("2015 Genel Seçimleri”, 2015; “2015 Türkiye Araştırma Şirketleri”, 2015).

Tablo 5: 7 Haziran 2015 Genel Seçim Sonuçları ve Kamuoyu Araştırma Sonuçlarının Karşılaştırması

\begin{tabular}{|c|c|c|c|c|c|c|c|c|c|c|c|}
\hline 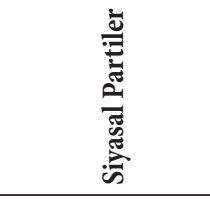 & 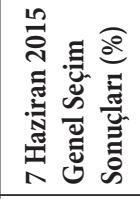 & 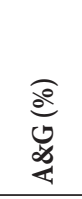 & $\begin{array}{l}\stackrel{0}{0} \\
\text { a } \\
\text { o } \\
0\end{array}$ & 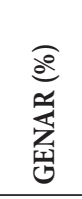 & $\begin{array}{l}\widehat{\varrho} \\
\text { o } \\
\text { o }\end{array}$ & 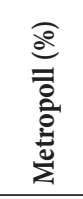 & 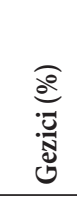 & 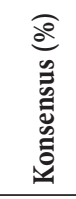 & $\begin{array}{l}\widehat{o} \\
\text { a } \\
\text { zo } \\
\text { o }\end{array}$ & $\frac{\widehat{\varrho}}{\frac{a}{4}}$ & 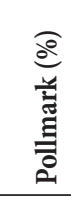 \\
\hline AK Parti & $\% 40,87$ & 42 & 41 & 43,8 & 46 & 41 & 39,3 & 43,9 & 41 & 47 & 49,40 \\
\hline Sapma Oranı(\%) & & $+1,13$ & $+0,13$ & $+2,93$ & $+5,13$ & $+1,13$ & $-1,57$ & $+3,03$ & $+0,13$ & $+6,13$ & $+8,53$ \\
\hline CHP & $\% 24,95$ & 27 & 27,8 & 25,6 & 25,3 & 27,6 & 28,5 & 26,7 & 26 & 24 & 23,50 \\
\hline Sapma Oranı(\%) & & $+2,05$ & $+2,85$ & $+0,65$ & $+0,35$ & $+0,65$ & $+3,55$ & $+1,75$ & $+1,05$ & $-0,95$ & $-1,45$ \\
\hline MHP & $\% 16,29$ & 16 & 14,8 & 15,9 & 15,5 & 16 & 17,2 & 15,8 & 18,1 & 14 & 15 \\
\hline Sapma Oranı(\%) & & $-0,29$ & $-1,49$ & $-0,39$ & $-0,79$ & $-0,29$ & $+0,91$ & $-0,49$ & $+1,81$ & $-2,29$ & $-1,29$ \\
\hline HDP & $\% 13,12$ & 12 & 12,6 & 10,8 & 9 & 11,5 & 12,4 & 9,7 & 10,4 & 9 & 8 \\
\hline Sapma Oranı(\%) & & $-1,12$ & $-0,52$ & $-2,32$ & $-4,12$ & $-1,62$ & $-0,72$ & $-3,42$ & $-2,72$ & $-4,12$ & $-5,12$ \\
\hline
\end{tabular}


7 Haziran 2015 Genel Seçimleri'nde AK Parti'nin oy oranına en yakın sonuca \%0,13 farkla KONDA ve SONAR, CHP'nin oy oranına en yakın sonuca \%0,65 farkla GENAR ve Metropoll, MHP'nin oy oranına en yakın sonuca \%0,29 farkla A\&G ve Metropoll, HDP'nin oy oranına en yakın sonuca \%0,52 farkla KONDA ulaşmıştır. 10 araştırmanın tamamında AK Parti kesin seçim sonuçlarından yüksek, HDP ise düşük oranda gösterilmiştir. Araştırma sonuçlarına bakıldığında şirketlerin seçim sonuçlarına en yakın oranlara ulaştığı siyasal partinin MHP olduğu görülmektedir.

\section{Kasım 20 I5 Genel Seçimleri}

1 Kasım 2015 Genel Seçimlerine katılım oranı \%85,23 seviyesinde olmuştur. Tablo 6'da kesin seçim sonuçları, kamuoyu araştırma şirketlerinin sonuçları ve bu sonuçlar arasındaki sapma oranları görülmektedir (“İşte ORC’nin son”, 2015; “AK Parti yüzde 44”, 2015; Çetin 2015; “En son erken seçim”, 2015; “AKP 1 Kasım'da”, 2015).

Tablo 6: I Kasım 2015 Genel Seçim Sonuçları ve Kamuoyu Araştırma Sonuçlarının Karşılaştırması

\begin{tabular}{|c|c|c|c|c|c|c|c|c|c|c|c|}
\hline Siyasal Partiler & $\begin{array}{l}1 \text { Kasım Genel } \\
\text { Seçim Sonuçları } \\
(\%)\end{array}$ & 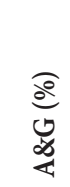 & 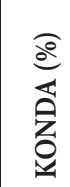 & 高 & 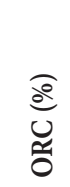 & 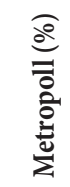 & 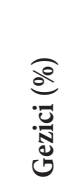 & 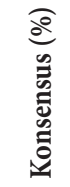 & 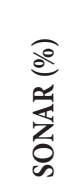 & $\frac{a}{o}$ & 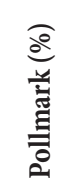 \\
\hline AK Parti & 49,5 & 47,2 & 41,7 & 47,7 & 43,3 & 43,3 & 43 & 43 & 40,5 & 39,2 & 43,9 \\
\hline Sapma Oranı(\%) & & $-2,3$ & $-7,8$ & $-1,8$ & $-6,2$ & $-6,2$ & $-6,5$ & $-6,5$ & -9 & $-10,3$ & $-5,6$ \\
\hline CHP & 25,3 & 25,3 & 27,9 & 25,1 & 27,4 & 26,9 & 26,1 & 28,6 & 27,3 & 26,4 & 25,4 \\
\hline Sapma Oranı(\%) & & 0 & $+2,6$ & $-0,2$ & $+2,1$ & $+1,6$ & $+0,8$ & $+3,3$ & +2 & $+1,1$ & $+0,1$ \\
\hline MHP & 11,9 & 13,5 & 14,2 & 13,4 & 14 & 14,8 & 14,9 & 13,1 & 15,2 & 16,2 & 14,8 \\
\hline Sapma Oranı(\%) & & $+1,6$ & $+2,3$ & $+1,5$ & $+2,1$ & $+2,9$ & +3 & $+1,2$ & $+3,3$ & $+4,3$ & $+2,9$ \\
\hline HDP & 10,7 & 12,2 & 13,8 & 8,9 & 12,2 & 13,4 & 12,2 & 11,9 & 13,1 & 14,1 & 12,3 \\
\hline Sapma Oranı(\%) & & $+1,5$ & $+3,1$ & $-1,8$ & $+1,5$ & $+2,7$ & $+1,5$ & $+1,2$ & $+2,4$ & $+3,4$ & $+1,6$ \\
\hline
\end{tabular}

1 Kasım 2015 Genel Seçim sonuçları hem Türk hem de dünya kamuoyunda dikkatle takip edilmiş ve çıkan sonuçlar medyada geniş şekilde yankılanmıştır. Seçim öncesinde yapılan kamuoyu araştırmalarının çeşitli şekillerde bir beklenti oluşturduğu yadsınamaz bir gerçektir. Buna bağlı olarak da AK Parti ve HDP’nin oy oranlarıyla araştırma sonuçları arasında büyük farklar olması siyasal iletişim sürecinde kamuoyu araştırma şirketlerinin ve araştırmaların güvenilirliği sorgulanmasına sebep olmuştur. Bu seçimlerde AK Parti'nin oy oranına en yakın sonuca \%1,8 farkla GENAR, MHP'nin ve HDP’nin oy oranına en yakın sonuca \%1,2 farkla Konsensus ulaşmıştır. CHP’nin oy oranı ise, A\&G tarafından birebir tespit edilmiştir. 10 kamuoyu araştırmasının tamamının AK Parti’nin oy oranını kesin seçim sonuçlarından düşük, MHP’nin oy oranını ise kesin seçim sonuçlarından yüksek bulması dikkat çekici bir neticedir. 


\section{Nisan 2017 Anayasa Değişikliği Referandumu}

16 Nisan 2107 Anayasa Değişikliği Referandumu Türk siyasi hayatının kırılma noktalarından biri olmuştur. Bu referandumla Türkiye’nin yönetim sistemi çok önemli bir değişim sürecine girmiştir. Bu süreç öncesinde yayınlanan kamuoyu araştırma sonuçları da gündemde önemli bir yer işgal etmiş ve çoğu kez seçimlerin kaderini etkileyecek güce sahip olup olmadığı tartışılmıştır. Bu çerçevede referandum sonuçları ile kamuoyu araştırma şirketlerinin anket sonuçlarının karşılaştırılması şu şekildedir ("16 Nisan sandık ve seçmen”, 2017; “Andy-Ar’ın son”, 2017; “İşte Adil Gür'ün”, 2017; “Son referandum anketi”, 2017; “Avrasya Araştırma’nın son”, 2017; "Referandum anket sonuçları", 2017; “İVEM’in anketinde”, 2017; “Adil Gür'ün anketi”, 2017):

Tablo 7: Referandum Sonuçları ve Kamuoyu Araştırma Sonuçlarının Karşılaştırması

\begin{tabular}{|l|l|l|l|l|l|l|l|l|}
\hline & & & & & & & \\
\end{tabular}

14 araştırma şirketi arasında KONDA, referanduma yönelik araştırmasıyla ilgili yayınladığı detaylı raporla ve web sitesinden yaptıkları bilgilendirmelerle diğer şirketlere göre daha güvenilir bir imaj çizmektedir. Daha önceki referandumlarda, genel ve yerel seçimlerde de olduğu gibi 16 Nisan 2017 Anayasa Değişikliği Referandumu'nda da araştırma şirketlerinin önemli bir bölümü bilimsel nedenlerle açıklanamayacak şekilde yanlış sonuçlara ulaşmışlardır. 1 Kasım 2015 Genel Seçimleri’ne en yakın sonucu bulan A\&G Araştırma Şirketi bu referandumda \%9,4 oranında yanılmıştır. Araştırma sonuçlarıyla seçim sonuçları arasındaki bu büyük farklar, kasıtlı olarak yapılmasalar dahi, seçmenleri siyasal katılma aşamasında çeşitli şekillerde etkilemektedir. 


\section{Haziran 2018 Genel Seçimleri}

24 Haziran 2018 Genel Seçimleri’ne katılım oranı \%86,22 olarak gerçekleşmiştir. Bu oran Avrupa’nın önemli ülkelerdeki siyasal katılma oranlarının oldukça üzerindedir. A\&G, GENAR, ANAR, Pollmark, THEMIS ve Andy-Ar şirketleri web sitelerinden ya da geleneksel medya üzerinden 24 Haziran 2018 Genel Seçimleri ve Cumhurbaşkanlığı Seçimi için kamuoyu araştırması yayınlamadıkları için Tablo 8'de bu şirketlere yer verilmemiştir. Tablo 8 'de 13 farklı kamuoyu araştırma şirketinin açıkladığı araştırma sonuçları yer almaktadır ("24 Haziran kesin", 2018; "Seçime 5 gün kala”, 2018; "KONDA’nın abonelerine gönderdiği”, 2018; "24 Haziran 2018 Milletvekili”, 2018; "Erken seçime doğru”, 2018; "Son anket sonuçları", 2018; "MAK anketine göre”, 2018; "PİAR Araştırma Şirketi’nden", 2018; "AKAM’ın son anketi”, 2018; "24 Haziran 2018'de yapılacak”, 2018; “İște son seçim anketi”, 2018; “Türkiye’nin nabzı Mayıs”, 2018; “Konsensus anket sonuçları”, 2018).

Tablo 8: 24 Haziran 2018 Genel Seçim Sonuçları ve Kamuoyu Araştırma Sonuçları Karşılaştırması

\begin{tabular}{|c|c|c|c|c|c|c|c|c|c|c|c|c|c|c|}
\hline & \begin{tabular}{|l}
24 Haziran \\
2018 Genel \\
Seçim \\
Sonuçları \\
$(\%)$
\end{tabular} & 部 & 帘 & 幽 & 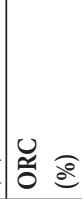 & 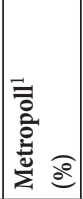 & 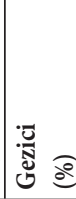 & 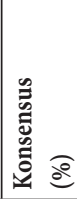 & 紊 & बै & 离 & $\sum^{\infty}$ & 崖 & $\sum^{\sum}$ \\
\hline AK Parti & 42,56 & 34,8 & 45,5 & 45 & 44,2 & 46,5 & 43,6 & 43,8 & 42,2 & 39,61 & 33,3 & 45,9 & 46,7 & 47,8 \\
\hline Sapma Ora & & $-7,76$ & $+2,94$ & $+2,44$ & $+1,64$ & $-7,16$ & $+1,04$ & $+1,24$ & $-0,36$ & $-2,95$ & $-9,26$ & $-7,76$ & $+4,14$ & $+5,24$ \\
\hline CHP & 22,65 & 23,4 & 26,1 & 23,5 & 24,5 & 34,8 & 26,7 & 27,4 & 28,2 & 22,61 & 19,4 & 40,4 & 26,3 & 25,2 \\
\hline Sapma & & $+0,75$ & $+3,45$ & $+0,85$ & $+1,85$ & $+0,85$ & $+4,05$ & $+4,75$ & $+5,55$ & $-0,04$ & $-3,25$ & $+6,45$ & $+3,65$ & $+2,55$ \\
\hline MHP & 11,10 & 7,3 & 7,3 & 9 & 10,5 & 46,5 & 5,3 & 7,4 & 7,1 & 2,29 & 4,4 & 45,9 & 6,9 & 9,6 \\
\hline Sapma & & $-3,8$ & $-3,8$ & $-2,1$ & $-0,6$ & $-7,16$ & $-5,8$ & $-3,7$ & -4 & $-8,81$ & $-6,7$ & $-7,76$ & $-4,2$ & $-1,5$ \\
\hline HDP & 11,70 & 14,1 & 11,6 & 9 & 11,9 & 10,1 & 12,1 & 9,7 & 10 & 11,39 & 8,7 & 13,4 & 11,2 & 8 \\
\hline Sapma Oranı(\%) & & $+2,4$ & $-0,1$ & $-2,7$ & $+0,2$ & $-1,6$ & $+0,4$ & -2 & $-1,7$ & $-0,31$ & -3 & $+1,7$ & $-0,5$ & $-3,7$ \\
\hline İYİ Parti & 9,96 & 17,2 & 8,5 & 8,5 & 7,4 & 34,8 & 10,1 & 11,2 & 9,2 & 17,60 & 12,6 & 40,4 & 6,8 & 5,4 \\
\hline Sapma Oranı(\%) & & $+7,24$ & $-1,46$ & $+1,46$ & $-2,56$ & $+0,85$ & $+0,14$ & $+1,24$ & $-0,76$ & $+7,64$ & $+2,64$ & $+6,45$ & $-3,16$ & $-4,56$ \\
\hline
\end{tabular}

SONAR, AK Parti’nin oy oranına en yakın tahmini yapan araştırma şirketi olarak öne çıkmaktadır. Aynı şekilde HDP ve İYİ Parti’nin oy oranlarına son derece yakın anket sonuçları açıklamıştır. Ancak aynı şirket CHP’nin oy oranını tahmin etmede \%5,55 düzeyinde MHP'nin oy oranında ise, \%4 düzeyinde yanılmıştır. ORC Araştırma, bu seçimlerde araştırmaya dahil edilen dört siyasal partinin de oy oranlarına en yakın tahminleri yapan şirket olarak önemli bir başarı yakalamıştır. AKAM, ittifak yapan siyasal partilerin oy oranlarını açıklamak yerine ittifakların oy oranını açıklamıştır. Buna göre AKAM, Cumhur İttifakı ${ }^{4}$ oy oranını $\% 45,9$ olarak açıklamış,

1 Metropoll, ittifak yapan siyasal partilerin tek tek oy oranlarını açılamak yerine ittifakların oy oranını duyurmuştur.

2 REMRES, kararsız seçmenlerin oranını siyasal partilere dağıtılmamış şekilde araştırma sonuçlarını ilan etmiştir.

3 AKAM, ittifak yapan siyasal partilerin tek tek oy oranlarını açıklamak yerine ittifakların oy oranını açıklamıştır.

4 Cumhur İttifakı, AK Parti ve MHP'den oluşmaktadır. 
Millet İttifakı ${ }^{7}$ oy oranını ise \%40,4 düzeyinde vermiştir. Millet İttifakı Saadet Partisi’nin \%1,34 oy oranıyla \%33,95 oy oranına ulaşmıştır.

\section{Haziran 2018 Cumhurbaşkanlığı Seçimi}

Cumhurbaşkanlığ1 seçimine katılım oranı \%86,24 düzeyinde gerçekleşmiştir. Tablo 9'da 13 farklı kamuoyu araştırma şirketinin cumhurbaşkanlığ 1 seçimine yönelik açıkladığ 1 araştırma sonuçları yer almaktadır ("24 Haziran kesin”, 2018; "Seçime 5 gün kala”, 2018; "KONDA’nın abonelerine gönderdiği”, 2018; “24 Haziran 2018 Milletvekili”, 2018; “Erken seçime doğru”, 2018; "Son anket sonuçları", 2018; "MAK anketine göre”, 2018; "PİAR Araştırma Şirketi’nden”, 2018; "AKAM’ın son anketi”, 2018; “24 Haziran 2018'de yapılacak”, 2018; “İşte son seçim anketi”, 2018; “Türkiye’nin nabzı Mayıs” 2018).

Tablo 9: 24 Haziran 2018 Cumhurbaşkanlığı Seçim Sonuçları ve Kamuoyu Araştırma Sonuçları Karşılaştırması

\begin{tabular}{|c|c|c|c|c|c|c|c|c|c|c|c|c|c|c|}
\hline $\begin{array}{l}\text { Cumhurbaşkanı } \\
\text { Adayları }\end{array}$ & $\begin{array}{l}24 \text { Haziran } \\
2018 \text { Genel } \\
\text { Seçim } \\
\text { Sonuçları } \\
(\%)\end{array}$ & 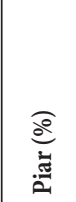 & $\frac{\widehat{a}}{a}$ & 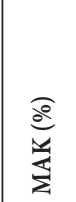 & 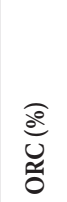 & 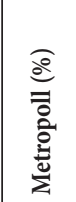 & 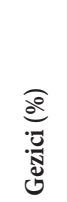 & 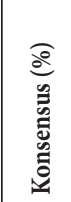 & 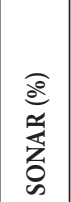 & $\overbrace{\substack{a \\
c}}^{a}$ & 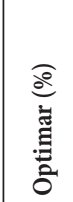 & $\frac{\widehat{e}}{\sum^{e}}$ & 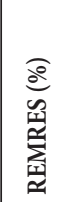 & 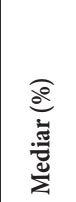 \\
\hline R. Tayyip Erdoğan & & 39,7 & 51,9 & 51,4 & 52,7 & 45,9 & 48,2 & 47,9 & 48,3 & 44,5 & 51,6 & 48,3 & 43,6 & 43,50 \\
\hline Sapma Oranı(\%) & & $-12,89$ & $-0,69$ & $-1,19$ & $-0,11$ & $-6,69$ & $-4,39$ & $-4,69$ & $-4,29$ & $-8,09$ & $-0,99$ & $-4,29$ & $-8,99$ & $-9,09$ \\
\hline Muharrem İnce & 30,64 & 26 & 28,0 & 23,9 & 29,2 & 20,1 & 29,1 & 26,8 & 31,4 & 28,3 & 28 & -- & 29,5 & 22,20 \\
\hline Sapma Oranı(\%) & & $-4,64$ & $-2,64$ & $-6,74$ & $-1,44$ & $-10,54$ & $-1,54$ & $-3,84$ & $+0,76$ & $-2,34$ & $-2,64$ & -- & $-1,14$ & $-8,44$ \\
\hline Selahattin Demirtaş & 8,40 & 11,1 & 9,0 & 9,6 & 8,4 & 11,4 & 10,0 & 9,7 & 8,2 & 11,5 & 10,3 & 7,6 & 11,4 & 12,79 \\
\hline Sapma Oranı(\%) & & $+2,7$ & $+0,6$ & $+1,2$ & 0 & +3 & $+1,6$ & $+1,3$ & $-0,2$ & $+3,1$ & $+1,9$ & $-0,8$ & +3 & $+4,39$ \\
\hline Meral Akşener & 7,29 & 21,2 & 10,2 & 12,3 & 8,6 & 11,2 & 11,4 & 14,8 & 9,5 & 13,5 & 8,5 & 5,5 & 12,3 & 19,31 \\
\hline Sapma Oranı(\%) & & $+13,91$ & $+2,91$ & $+5,01$ & $+1,31$ & $+3,91$ & $+4,11$ & $+7,51$ & $+2,21$ & $+6,21$ & $+1,21$ & $-1,79$ & $+5,01$ & $+12,02$ \\
\hline Temel Karamollaoğlu & 0,89 & 1,8 & 0,7 & 2,2 & 0,9 & 1,7 & 1,2 & 0,7 & 2,1 & -- & 1,1 & -- & 0,3 & 1,61 \\
\hline Sapma Oranı(\%) & & $+0,91$ & -0.19 & $+1,31$ & $+0,01$ & $+0,81$ & $+0,31$ & $-0,19$ & $+1,21$ & -- & $+0,21$ & -- & $-0,59$ & $+0,72$ \\
\hline Doğu Perinçek & 0,20 & 0,1 & 0,1 & 0,6 & 0,2 & 0,1 & 0,1 & 0,1 & 0,5 & -- & 0,5 & -- & 0,2 & 0,60 \\
\hline Sapma Oranı(\%) & & $-0,1$ & $-0,1$ & $+0,4$ & 0 & $-0,1$ & $-0,1$ & $-0,1$ & $+0,3$ & -- & $+0,3$ & -- & 0 & $+0,4$ \\
\hline
\end{tabular}

13 araştırma şirketinin tamamının Erdoğan’ın oy oranını seçim sonucundan düşük gösterdiği belirlenmiştir. ORC Araştırma, \%-0,11 sapmayla Erdoğan’ın oy oranına en yakın tahmini yapan şirket olarak gözükmektedir. İnce’nin oy oranına en yakın tahmini \%+0,76 sapma oranıyla SONAR yapmıştır. SONAR dışındaki 11 şirket İnce'nin oy oranı seçim sonuçlarından daha düşük göstermiştir. Demirtaş’ın oy oranını ORC Araştırma \%100 oranında doğru tahmin

5 AKAM, Temel Karamollaoğlu ve Doğu Perinçek'in oy oranlarını açıklamamıştır.

6 IVEM Araştırma, kamuoyu araştırmasını Ocak 2018 tarihinde yapmıştır. Cumhurbaşkanı adaylıkları resmi olarak açıklanmayan Muharrem İnce, Temel Karamollaoğlu ve Doğu Perinçek bu nedenle araştırmada yer almamıştır..

7 Millet İttifakı, CHP, İYI Parti ve Saadet Partisi'nden oluşmaktadır. Saadet Parti’si 24 Haziran 2018 Genel Seçimleri sonrasında Türkiye Büyük Millet Meclisi’nde grup oluşturacak çoğunluğa ulaşamaması sebebiyle çalışmaya dahil edilmemiştir. 
ederek önemli bir başarıya imza atmıştır. 13 şirketin 11'inin Demirtaşıı oy oranını seçim sonuçlarından daha yüksek gösterdiği belirlenmiştir. Optimar Araştırma, \%+1,21 sapma oranıyla Akşener'in oy oranına en yakın tahmini gerçekleştirmiştir. 13 şirketin 12'si Akşener'in oy oranını seçim sonuçlarından daha yüksek göstermiştir. PİAR Araştırma ise, \%+13,91 sapma oranıyla Akşener'in oy oranından en farklı tahmini yapan şirket olarak belirlenmiştir. KONDA ve Konsensus Karamollaoğlu'nun oy oranına en yakın tahmini yapan şirketler olarak öne çıkmaktadır. Karamollaoğlu’nun oy oranını tahmin etmede araştırma şirketlerinin tamamının başarılı olduğu görülmektedir. ORC ve REMRES şirketleri Perinçek'in oy oranını \%100 oranında doğru tahmin etmiştir. Diğer şirketlerin de Perinçek'in oy oranına son derece yakın tahminler yaptığ 1 söylenebilir.

Araştırma şirketleri şeffaflık ilkesi gereği seçimlere yönelik kamuoyu araştırmalarını tüm metodolojik özellikleriyle birlikte kamuoyuyla paylaşmalıdırlar. Ancak incelenen 18 kamuoyu araştırma şirketinden sadece KONDA ve ORC yaptığı araştırma sonuçlarını detaylı bir şekilde internet sitesi üzerinden kamuoyuna duyurmuştur. Ayrıca Metropoll, 30 Mart 2014 Yerel Seçimleri ve 16 Nisan 2017 Anayasa Değişikliği Referandumu dışındaki diğer 7 seçimle ilgili yaptığı araştırma sonuçlarını yöntemsel özellikleriyle birlikte internet sitesinde ilan etmiş̧ir. Şirketlerin araştırmaların künyesini toplumla paylaşmasının seçmenler nezdinde şirketlere karşı güven oluşmasına katkı sağladığı söylenebilir. Bu durum kamuoyu araştırma şirketlerinin manipülasyon yapma ve medyada yer alma gibi kaygılar taşımadığına işaret etmektedir. A\&G ile Gezici Araştırma şirketleri ise, seçimlere yönelik kamuoyu araştırmalarının sonuçlarına internet sitelerinde yer vermemiştir. Araştırma şirketlerinin internet sitelerinin içeriklerinin incelenmesi sonucunda araştırma şirketlerinin seçim sonuçlarına yakın tahminler gerçekleştirdiği araştırma sonuçlarını internet sitelerinde yayınlama eğilimde olduğu görülmüştür.

Kamuoyu araştırma sonuçları ile kesin seçim sonuçları arasındaki tutarsızlıklar ve aşırı sapmaların kamuoyu araştırma şirketlerinin bilimselliğine duyulan güveni teorik olarak azalttığ 1 söylenebilir. Orta ve uzun vadede ise, kamuoyu araştırmaları ve bu araştırmaları yapan şirketler itibarsızlaşmaktadır. Ancak bu nokta seçmenlerin kamuoyu araştırmalarındaki sonuçların tutarlılığını ne ölçüde dikkate aldığını ortaya koyan genel geçer ampirik araştırma bulgusu son derece kısıtlıdır. Diğer taraftan, fotoğrafın bütününe bakıldığında KONDA, ORC, Metropoll ve A\&G’nin araştırmalarındaki birkaç büyük orandaki hatalı sonuçlar çıkarıldı̆̆ı bu şirketlerin \%2-3 hata payı ile seçim sonuçlarına yakın araştırma sonuçları yayınladığı tespit edilmiştir. Diğer yandan araştırma şirketleri bazı seçim sonuçlarına son derece yakın tahminler içeren anketler yayınlarken bazı seçimlerde ise, bilimsel nedenlerle açılanması oldukça güç büyük farklar gösteren araştırmalar gerçekleştirmektedir. 12 Haziran 2011, 7 Haziran 2015, 1 Kasım 2015 Genel Seçimleri ve 30 Mart 2014 Yerel Seçimlerỉnde kesin seçim sonuçları ile araştırma sonuçları arasındaki en büyük sapma oranları AK Parti’nin oy oranlarında olduğu görülmüştür. Gezici Araştırma Şirketi’nin araştırma sonuçları açıkladığı dört seçimde de CHP’yi kesin seçim sonuçlarından yüksek gösterdiği tespit edilmiştir. Kamuoyu araştırma sonuçları ile seçim sonuçları arasındaki tutarsızlı̆̆ın bilimsel nedenlerle açılanamaması araştırma şirketlerinin liyakat sorununu gündeme getirmektedir. 


\section{Sonuç}

Seçimlere dönük kamuoyu araştırmalarının seçmenlerin oy tercihlerini doğrudan etkilediğini söylemek güçtür. Seçmenin oy verme davranışını etkileyen çok sayıda farklı etmen vardır. Diğer yandan, seçimlere dönük kamuoyu araştırmalarının siyasal iletişim aracı olarak kullanıldığ görülmektedir. Kamuoyu araştırmaları, seçmeni teşvik etmek, medyada yer almak, rakiplerin motivasyonunu kırmak, seçmenleri ve teşkilatları konsolide etmek amaçlarıyla seçim kampanyası dönemlerinde kullanılmaktadır. Literatürde kamuoyu araştırmalarının siyasal partiler ve araştırmaları yapan şirketler tarafından medyaya servis edildiği ve medyanın gündem oluşturma, reyting, satış, tiraj ve web ortamında "tıklanma” kaygısıyla bu sonuçları kullandığı yaygın şekilde tartışılmaktadır. Medya ve siyasal partiler, güven kazanmak yerine gündem oluşturmayı ve seçmeni baskı altına almayı yeğler gözükmektedir. Bu noktada güven inşa etme merkezine dayanan siyasal katılma sürecinde doğru bir strateji izlendiğini söylemek güçtür.

$\mathrm{Bu}$ araştırmanın sonuçları genel seçimler, yerel seçimler, cumhurbaşkanlığı seçimleri ve referandum sonuçları olmak üzere dört kategoride ele alınabilir:

- 2010 ve 2017 Anayasa Değişikliği Referandumu sonuçları incelendiğinde; 2010'da KONDA, GENAR, Pollmark ve Metropoll \%1 civarı sapma oranıyla seçim sonuçlarına en yakın araştırma sonuçlarını açıklayan şirketler olarak öne çıkmışlardır. 2017’de KONDA, GEZİCİ ve ANAR referandum sonuçlarına çok yakın sonuçları açıklayan şirketler olmuşlardır. Bu referandumda $A \& G$ ve AKAM’’n araştırma sonuçlarında \%9 civarında sapma olmuştur.

- 2014 Yerel Seçimlerinde araştırma sonuçlarının seçim sonuçlarını öngörmede zorlandığı görülmektedir. Ancak incelenen araştırma sonuçları arasında SONAR ve ORC Araştırma’nın sonuçları diğer sonuçlardan daha tutarlıdır. Diğer taraftan Pollmark’’n araştırma sonuçlarının sapma oranlarının daha fazla olduğu görülmektedir.

- 2014 Cumhurbaşkanlığı Seçimi’nde en başarılı sonuçlara Pollmark’ın ulaştığı görülmektedir. Sapma oranı en fazla olan araştırma ise Metropoll'e aittir. 2018 Cumhurbaşkanlığ 1 Seçiminde ise, en başarılı şirketin ORC Araştırma, en başarısız şirketin de PİAR olduğu tespit edilmiştir.

- Genel seçim sonuçlarıyla araştırma sonuçları karşılaştırıldığında; 2011 Genel Seçimleri’nde incelenen 9 şirketten 8'i başarılı sonuçlar açıklarken Metropoll özellikle AK Parti’nin oy oranında \%-7,8 oranında yanılmıştır. Bu seçimlerde en yakın tahminleri SONAR yaparken, sapma oranları en fazla olan araştırmayı Pollmark gerçekleştirmiştir. 7 Haziran 2015 Genel Seçimleri'nde en başarılı araştırma sonuçlarını Metropoll, en başarısız araştırma sonuçlarını ise Pollmark yayınlamıştır. 1 Kasım 2015 Genel Seçimleri’nde öngörüleri başarılı olan şirket A\&G olmuştur. GENAR ve ANAR'ın araştırmaları sapma oranları en fazla olan sonuçları içermektedir. 24 Haziran 2018 Genel Seçimleri’nde seçim sonuçlarına en yakın tahminleri ORC Araştırma yapmıştır. AKAM ve REMRES’in seçim sonuçlarından en farklı araştırma sonuçlarını açıklayan şirketler olduğu tespit edilmiştir. İncelenen şirketler bazı seçimlerde son derece başarılı tahminler yaparken, bazı seçimlerde bilimsel yöntemlerle açıklanamayacak 
derecede sapma oranı yüksek araştırma sonuçlarına ulaşmışlardır. Genel ve yerel seçimlerde en fazla sapma oranlarının AK Parti’nin oy oranlarında olduğu belirlenmiştir.

Kamuoyu araştırmalarının büyük çoğunluğunda bilimsellik ve şeffaflık kriterleri olan ESOMAR (European Society for Opinion and Marketing Research) ve WAPOR (World Association for Public Opinion Research) ilkelerini benimsememeleri güvenilirliği sarsmaktadır. Ayrıca, kamuoyu araştırmaları rapor olarak yayınlanmamaktadır. O nedenle, araştırmalardaki hata payları, güven aralığı, örneklem sayısı, soru formları net olarak bilinmemektedir. Ayrıca araştırmaların güvenilir olması için çalışmaları kimin fonladığı, kimin adına yapıldığı, kimin desteklediği ve sonuçlardaki sapmaların nedenleri şeffaf şekilde kamuoyuyla paylaşılmalıdır. Seçimlere yönelik kamuoyu araştırmalarının metodolojik niteliklerinin basında yer almaması veya yöntem konusunda bilgilerin basında çok kısıtlı şekilde verilmesi bilimsellik ve şeffaflık ilkelerine uyulmadığı kuşkularını doğurmaktadır. Bu çalışma seçimlere yönelik kamuoyu araştırma sonuçlarının seçmeni nasıl etkilediğini, hangi sonucun hangi siyasal parti sempatizanında nasıl algılandığını ve kararsız seçmenlerin oy verme davranışında kamuoyu araştırma sonuçlarını dikkate alıp almadığını tespit etmeye dönük kantitatif araştırmalar yapılması gerektiği sonucunu doğurmuştur. Kamuoyu araştırmaları alanındaki gelişme, ticarileşme; medya, siyaset ve çıar ilişkileri ile konunun manipülasyona ve dezenformasyona açık olması bu alanla ilgili yasal düzenlemeler yapılması gerektiğini göstermektedir.

Siyasilerle kamuoyu araştırma şirketlerinin doğrudan ve dolaylı bağlantıları ile araştırma sonuçlarının yayınlandığı medya kuruluşları, bunun yanı sıra ısmarlama kamuoyu araştırmalarının varlığı kamuoyu araştırmalarının güvenilirliği konusunda kaygıları artırmaktadır. Kesin seçim sonuçlarıyla kamuoyu araştırma sonuçları arasında ciddi farklılıklar olmasına rağmen araştırma sonuçlarının yayınlanmaya devam etmesinin nedenleri şunlar olabilir: 1) Seçmeni harekete geçirmek, 2) İktidar yolunda gidildiği mesajı vermek, 3) Seçmeni seçimi kazanacak partiye yönlendirmek, 4) Seçmenlerin rehavete girmesini engellemek, 5) Rakip siyasal partilerin oylarının azaldığını göstermek, 6) Teşkilatları ve üyeleri motive etmek, 7) Medyada yer almak, 8) Seçmenin sandığa gitmesini engellemek.

Kamuoyu araştırmaları geleneksel medyada olduğu kadar yeni medyada da oldukça fazla dikkat çekmektedir. Kamuoyu araştırma şirketlerinin ve bu şirketlerin sahiplerinin sosyal medya hesaplarından araştırma sonuçları yayınlanarak şirketler ve araştırmacılar kendi tanıtımlarını yapmakta ve gündeme gelmeye çalışmaktadır. Aynı şekilde siyasal parti liderleri ve partililer de sosyal medya hesaplarından partilerini önde gösteren araştırma sonuçlarını paylaşarak seçim sonuçlarıyla ilgili olumlu bir atmosfer oluşturmaya çalışmaktadırlar.

Kamuoyu araştırmalarının seçimlerden önce yayınlanmasıyla ilgili yasal düzenlemeler yapılmalıdır. Bu konuda dünyadaki farklı uygulamalar incelenerek kamuoyu araştırma şirketlerine ve medya kuruluşlarına kanuni yükümlülükler getirilmelidir. Kamuoyu araştırmalarının siyasal partiler ve medya tarafından bir siyasal iletişim aracı ve gündem belirleme unsuru olarak kullanılmasının önüne geçilmeli, seçmenlerin zihninin iğfal edilmesine ket vurulmalıdır. 
Siyasetçilerin, medyanın ve kamuoyu araştırmalarının genel olarak negatif imajı, siyasal iletişim sürecine olumsuz yansımaktadır. Siyasal katılmada güven çok boyutlu ve zor bir konudur. Bu açıdan siyasal katılmanın politikacılar ve medya açısından kamuoyu araştırmaları ekseninde ayrı ayrı ele alınması gerekmektedir. Kamuoyu araştırmalarının medya aracılığıyla seçmenleri manipüle etmesi siyasal katılmayı çeşitli şekillerde etkileyebilmektedir. Politikacıların ve medyanın itibar sorunu kamuoyu araştırma sonuçlarının güvenilirliğini de dolaylı şekilde belirlemektedir. Ancak siyasiler açısından politikaların belirlenmesi ve halkın tepkilerinin ölçülmesi anlamında araştırmalar yararlı olabilmektedir. Araştırma sonuçlarına medya açısından baktığımızda ise, vatandaşların "ne hakkında konuşacağı"nı belirlemek, hükümetleri baskı altına almak ya da desteklemek açısından araştırmaların güç ilişkilerine hizmet ettiği söylenebilir. Ancak karşı sav olarak seçimlere yönelik kamuoyu araştırmalarının seçmenleri yönlendirmediğini ve seçmenlerin oy verme davranışında bu araştırmaların etkisinin olmadığını test eden deneysel çalışma verileri de bulunmamaktadır. 


\section{Kaynakça}

4 farklı araştırma şirketi. (2015, 4 Ekim). Milliyet. 05.10.2015 tarihinde http://www.milliyet.com.tr/4-farkliarastirma-sirketi /siyaset/detay/1837490/default.htm adresinden edinilmiștir.

6 şirketin Cumhurbaşkanı seçimi anket sonucu. (2015, 30 Mayıs). İnternethaber. 26.09.2015 tarihinde http://www.internethaber.com/6-sirketin-cumhurbaskani-secimi-anket-sonucu-697817h.htm adresinden edinilmiştir.

16 Nisan sandık ve seçmen analizi raporu. (2017, 28 Nisan). KONDA. 30.04.2017 tarihinde http://KONDA. com.tr/wpcontent/uploads/2017/04/KONDA_16Nisan2017SandikveSecmenAnaliziRaporu.pdf adresinden edinilmiştir.

24 Haziran 2018 Milletvekili Genel Seçimi ve Cumhurbaşkanlığ Seçimi Seçmen Tercihleri. (2018, 21 Haziran). ORC Araşırma. 22.06.2018 tarihinde http://orcarastirma.com.tr/wp-content/ uploads/2018/06/24-HAZ\%C4\%B0RAN-M\%C4\%B0LLETVEK\%C4\%B0L\%C4\%B0GENEL-SE\%C3\% 87\%C4\%B0M\%C4\%B0-VE-CUMHURBA\%C5\%9EKANLI\%C4\%9EI-

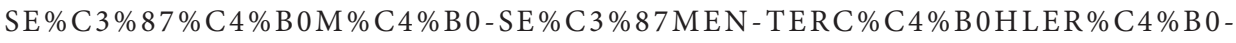
ARA\%C5\%9ETIRMASI.pdf adresinden edinilmiştir.

24 Haziran 2018'de yapılacak ola Cumhurbaşkanlığı seçiminde hangi adaya oy vereceksiniz?. (2018, 17 Haziran). Optimar. 23.06.2018 tarihinde http://www.optimar.com.tr/ adresinden edinilmiștir.

24 Haziran kesin seçim sonuçları Resmi Gazete'de. (2018, 5 Temmuz). TRT Haber. 06.07.2018 tarihinde http:// www.trthaber.com/haber/gundem/24-haziran-kesin-secim-sonuclari-resmi-gazetede-373622.html adresinden edinilmişir.

30 Mart 2014 Yerel Seçimleri Belediye Meclis Üyeliği Sonuçları. (2014, 15 Nisan). YSK.gov.tr. 06.10.2015 tarihinde http://ysk.gov.tr/ysk/content/conn/YSKUCM/path/Contribution\%20Folders/ HaberDosya/BelediyeMeclisUyeligi2014.pdf adresinden edinilmiştir.

2015 Genel Seçimleri 5 ankette farklı sonuç. (2015, 1 Haziran). İnternethaber. 05.10.2015 tarihinde http:// www.internethaber.com/2015-genel-secimleri-5-ankette-farkli-sonuc-781229h.htm adresinden edinilmiştir.

2015 Türkiye Araştırma Şirketleri Anket Sonuçları. (2015, 6 Ekim). Yeni Şafak. 23.12.2017 tarihinde http://www.yenisafak.com/secim-2015-kasim/genel-secim-pollmark-anket-sonuclari adresinden edinilmiştir.

Abadan Unat, N. (1988). Türkiye’de toplumsal değişme, piyasa araştırmaları ve kamuoyu yoklamaları. Kamuoyu Araştırmaları Birinci Uluslar Arası Sempozyumu. Ankara Üniversitesi BYYO Yayınları, s. 29-47.

Adil Gür'ün anketi. (2017, 5 Nisan). Ahaber. 14.04.2017 tarihinde http://www.ahaber.com.tr/ gundem/2017/04/14/iste-adil-gurun-beklenen-anketi adresinden edinilmiştir.

AK Parti yüzde 44. (2015, 15 Ekim). Sabah. 02.11.2015 tarihinde http://www.sabah.com.tr/fotohaber/ gundem/ak-parti-yuzde-44e-ulasti?tc=13\&page=9 adresinden edinilmiştir.

AKAM'in son anketi. (2018, 23 Haziran). Cumhuriyet. 24.06.2018 tarihinde http://www.cumhuriyet.com.tr/ haber/siyaset/1005930/AKAM_in_son_anketi__Cumhurbaskanligi_ikinci_tura_kaliyor__HDP_ baraji_geciyor.html adresinden edinilmiştir.

AKP 1 Kasım'da iktidar olacak mı? (2015, 11 Ekim). Meydan Gazetesi. 03.11.2015 tarihinde http://www. meydangazetesi.com.tr/aktuel/akp-1-kasim-da-iktidar-olacak-mi-hdp-baraji-gececek-mi-anargezici-metropoll-6-ekim-2-kasim-2015-haberleri-h26599.html adresinden edinilmiștir. 
Andy-Ar'ın son anketinde 'Evet' oyları yüzde 53. (2017, 5 Nisan). Sputniknews. 16.04.2017 tarihinde https://tr.sputniknews.com/politika/201704141028078000-and-arin-son-anketinde-evet-oylari/ adresinden edinilmiştir.

Atabek, N. (2003). Türk basınında kamuoyu araştırmaları. İletişim, (17), s. 1-28.

Avrasya Araştırma’nın son referandum anketi. (2017, 3 Nisan). Birgün. 12.04.2017 tarihinde http://www. birgun.net/haber-detay/avrasya-arastirma-nin-son-referandum-anketi-hayir-yuzde-57-75-154969. html adresinden edinilmiştir.

Balcı, A. ve Ayhan, B. (2004). Seçmen tercihlerinin belirlenmesine yönelik yapılan kamuoyu araştırmalarında güvenilirlik ve geçerlilik problemleri: 28 Mart 2004 Yerel Seçimleri örneği. Sosyal Bilimler Enstitüsü Dergisi, (11), s. 135-167.

Bütün anket şirketlerinin referandum anket sonuçları. (2015, 8 Eylül). Wordpress. 26.09.2015 tarihinde https://anayasareferandumu.wordpress.com/2010/09/08/butun-anket-sirketlerinin-referandumanket-sonuclari-ve-sirketlerin-bilgileri/ adresinden edinilmiştir.

Champagne, P. (1995). Kamuoyu yoklamaları, oy kullanma ve demokrasi. Hülya Tufan (Ed.), Kamuoyu kimin oyu? içinde (s. 143-176). İstanbul: Kesit Yayıncılık.

Çetin, R. (2015). 22 şirketin 7 Haziran'dan bugüne yaptığı 1 Kasım anketlerinden hangi sonuçlar çıtı? T24. com. 31.10.2015 tarihinde http://t24.com.tr/haber/21-anket-sirketi-7-hazirandan-bugune,314829 adresinden edinilmiştir.

Çoymak, A., Gheorghiu, M., Niens, U. ve Lyons, E. (2015). Vatandaşlığın psikolojisi ve politik güven”. Ö. Dirilen Gümüş (Ed.), Siyaset psikolojisi içinde (s. 257-280), İstanbul: Nobel Yayınları.

Çöllü, E. F. (2014). Kamuoyu araştırmalarında güvenilirlik ve geçerlilik. Selçuk Üniversitesi Sosyal Bilimler Meslek Yüksekokulu Dergisi. (10), s. 279-296.

Dahlgren, P. (2014). Participation and alternative democracy: Social media and their contingencies. P. Serra, E. Camilo ve G. Gonçalves (Ed.), Political participation and Web 2.0 içinde (s. 65-81), Covilha: Livros LabCom.

En son erken seçim anketleri. (2015, 7 Ekim). Köprübaşı. 02.11.2015 tarihinde http://www.koprubasi.tv/ gundem/en-son-erken-secim-anket-sonuclari-31-ekim-genar-anket-sonuclari-1-kasim-genelerken-secim-sonuclari-anketi-genar-arastirma-sirketi-erken-secim-starti-ogren-yarin-secimlernasil-gecicek-h13180.html adresinden edinilmiştir.

Erken seçime doğru. (2018, 25 Haziran). REMRES. 26.06.2018 tarihinde http://www.remres.com.tr/ filemanager/files/haziran\%202.pdf adresinden edinilmiştir.

ESOMAR (2006). ESOMAR kamuoyu araştırma sonuçlarının yayınlanmasına ilişkin uluslararası uygulama esaslarını da içeren ESOMAR/WAPOR kamuoyu araştırmaları rehberi. Tuad.org.tr. 28.03.2017 tarihinde http://tuad.org.tr/upload/files/ESOMAR_\%20Wapor_Kamuoyu_Arastirmalari_Rehberi. pdf adresinden edinilmiştir.

Güngör, N. (2013). İletişim kuramlar yaklaşımlar. Ankara: Siyasal Kitapevi.

Güz, N. (2005). Haberde yönlendirme ve kamuoyu araştırmaları. Ankara: Nobel Yayın Dağıtım.

İşte Adil Gür'ün beklenen anketi. (2017, 5 Nisan). Ensonhaber. 16.04.2017 tarihinde http://www.ensonhaber. com/orcnin-son-referandum-anketi-2017-04-14.html adresinden edinilmiştir.

İște ORC’nin son seçim anketi. (2015, 5 Ekim). Ensonhaber. 06.10.2015 tarihinde http://web.archive.org/ web/20120125040220/http://www.ensonhaber.com:80/iste-orcnin-son-secim-anketi-2011-12-13. html? adresinden edinilmiştir.

İşte Referandum'un resmi sonuçları. (2015, 23 Eylül). Sabah. 26.09.2015 tarihinde http://www.sabah.com.tr/ gundem/2010/09/23/iste_referandumun_resmi_sonuclari adresinden edinilmiştir. 
İşte son seçim anketi. (2018, 4 Ocak). Siyasetcafe. 25.01.2018 tarihinde https://www.siyasetcafe.com/isteson-secim-anketi-mhp-ve-iyi-partiye-buyuk-sok-30313h.htm adresinden edinilmiştir.

IVEM'in anketinde "evet” fark attı. (2017, 4 Nisan). Sonseçimanketi. 12.04.2017 tarihinde http://www. sonsecimanketi.com/ivem-anketinde-evet-fark-atti adresinden edinilmiştir.

Kalender, A. (2005). Siyasal iletişim seçmenler ve ikna stratejileri. Konya: Çizgi Kitapevi.

Kapani, M. (2013). Politika bilimine giriş. Ankara: Bilgi Yayınevi.

Kışlalı, A. T. (2010). Siyasal sistemler: Siyasal çatışma ve uzlaşma. Ankara: İmge Kitabevi.

KONDA’nın abonelerine gönderdiği bilgi notu. (2018, 22 Haziran). KONDA. 22.06.2018 tarihinde http:// KONDA.com.tr/tr/duyuru/KONDAnin-abonelerine-gonderdigi-bilgi-notu-21-haziran-2018/ adresinden edinilmiştir.

Konsensus anketi sonuçları 24 Haziran seçim anketi. (2018, 8 Haziran). İnternethaber. 08.06.2018 tarihinde http://www.internethaber.com/konsensus-anketi-sonuclari-24-haziran-secim-anketi-1878026h. htm adresinden edinilmiştir.

Lazersfeld, P. F., Berelson, B. ve Gaudet, H. (1955). The people's choice. New York: Columbia University Press. Le Bon, G. (2013). Kitleler psikolojisi. Ankara: Alter Yayınları.

MAK anketine göre seçimlerde ilk tur bıçak sırtı. (2018, 29 Mayıs). Sputniknews 30.05.2018 tarihinde https:// tr.sputniknews.com/analiz/201805231033553307-mak-danismanlik-24-haziran-anket/ adresinden edinilmiştir.

Marcus, G. E. ve Mackuen, M. B. (1993). Anxiety, enthusiasm and the vote: The emotional underpinnings of learning and involvement during presidential campaigns. American Political Science Review, 87(3), s. $672-685$.

Meray, S. (1954). Halk efkarı ve yoklanması. Ankara Üniversitesi SBF Dergisi, 9(3), s. 256-303.

Özbudun, E., Kalaycıoğlu, E. ve Köker, L. (1995). Türkiye’de demokratik Siyasal Kültür. Ankara: Türk Demokrasi Vakfi.

Özbudun. E. ve Hale, W. (2010). Türkiye'de İslamcılık, demokrasi ve liberalizm: AKP olayı. İstanbul: Doğan Kitap.

Özerkan, Ş. A. (1992). Kamuoyu yoklamalarından hiç korkmamak gerekir. İletişim Dünyası Dergisi, (1), s. 61-83.

Özkan, A. (2007). Siyasal iletişim stratejileri. İstanbul: Tasam Yayınları.

PİAR Araştırma Şirketi’nden 24 Haziran seçim anketi. (2018, 9 Haziran). Mynet. 10.06.2018 tarihinde http:// www.mynet.com/haber/secim/piar-arastirma-sirketi-nden-24-haziran-secim-anketi-ak-parti-veerdogan-bu-rakamlari-daha-once-gormemisti-4181200-1 adresinden edinilmiştir.

Referandum anket sonuçları. (2017, 3 Nisan). Indigodergisi. 12.04.2017 tarihinde https://indigodergisi. com/2017/04/referandum-anketi-sonuclari-tam-liste/ adresinden edinilmiştir.

Seçime 5 gün kala anketlerde son durum. (2018, 4 Temmuz). Ensonhaber. 05.07.2018 tarihinde http://www. ensonhaber.com/secime-5-gun-kala-anketlerde-son-durum.html adresinden edinilmiştir.

Seçime haftalar kala 5 farklı şirketin seçim anketi. (2015, 6 Ekim). Cumhuriyet. 06.10.2015 tarihinde http:// www.cumhuriyet.com.tr/haber/siyaset/37617/Secime_haftalar_kala_5_farkli_sirketin_secim_ anketi.html adresinden edinilmiştir.

Seçimi hangi anket şirketi bildi. (2011, 13 Haziran). Sabah. 25.09.2015 tarihinde http://www.sabah.com.tr/ gundem/2011/06/13/secimi-hangi-anket-sirketi-bildi adresinden edinilmiştir.

Sezgin, M. (2003). Siyasal nitelikli kamuoyu araştırmaları ve 24 Aralık 1995 genel seçimler örneği. Selçuk Üniversitesi Sosyal Bilimler Meslek Yüksekokulu Dergisi, (6), s. 55-75. 
Son anket sonuçları. (2018, 19 Haziran). Sözcü. 20.06.2018 tarihinde https://www.sozcu.com. tr/2018/gundem/son-anketler-24-haziran-yaklasirken-son-secim-anketlerine-gore-sonuclarneler-2473221/ adresinden edinilmiştir.

Son referandum anketi açıklandı. (2017, 5 Nisan). Sözcü. 16.04.2017 tarihinde http://www.sozcu.com. tr/2017/gundem/son-dakika-son-referandum-anketi-aciklandi-flas-sonuclar-var-1790998/ adresinden edinilmiştir.

SONAR ve GENAR seçim anketi. (2014, 14 Mart). Medyaline.07.10.2015 tarihinde http://www.medyaline. $\mathrm{com} /$ sonar-ve-genar-secim-anketi-sonuclari-2014-yerel-secimde-siyasi-partilerin-oyoranlari_80605.html adresinden edinilmiştir.

Temmuz ayında Cumhurbaşkanlığı tahminleri. (2014, 8 Temmuz). Seçimanketleri. 10.06.2018 tarihinde http://www.seçimanketleri-jgb.net/2014/07/temmuz-ay-itibariyle-cumhurbaskanlg.html adresinden edinilmiştir.

Tufan, H. (1995). Kamuoyu kimin oyu? İstanbul: Kesit Yayıncılık.

Turan, İ. (1976). Siyasal sistem ve siyasal davranış. İstanbul: Der Yayınları.

Türkiye Geneli Sonuçları. (2014, 11 Mart). ORC Araştırma. 22.12.2017 tarihinde http://www.orcarastirma. com.tr/wp-content/uploads/2014/03/turkiyegeneli.png adresinden edinilmiştir.

Türkiye’nin nabzı Mayıs 2018. (2018, 8 Haziran). Twitter. 08.06.2018 tarihinde https://twitter.com/metropoll adresinden edinilmiştir. 